\title{
Breaking the Silence: An Empirical Analysis of the Drivers of Internal Auditors' Moral Courage
}

\author{
Imen Khelil (IHEC Carthage, Tunisia) \\ Onsa Akrout (IHEC Carthage, Tunisia) \\ Khaled Hussainey (University of Portsmouth, UK) \\ Hédi Noubbigh (IHEC Carthage, Tunisia)
}

\begin{abstract}
Miss Imen Khelil is a PHD Student at IHEC Carthage, University of Carthage, Tunisia and at RIM-RAF, University of Manouba, Tunisia-department of Accounting-. She has an experience in teaching many courses in accounting. She has published in Managerial Auditing Journal and International Journal of Accounting, Auditing and Performance Evaluation. Her research interests include audit, ethics, moral courage and fraud reporting. Khalil_imen@yahoo.fr
\end{abstract}

Dr. Onsa Akrout She received her PhD from the IHEC Carthage in 2016. She has an experience in teaching many courses in accounting. Her research interests are mainly in the areas of behavioral research in accounting, data analysis and international accounting standards. onsa.ihec@gmail.com

Prof Khaled Hussainey is a Professor of Accounting and Financial Management at Portsmouth University. He has published more than 70-refereed papers in academic journals and international conferences proceedings. He has been awarded the prestigious 2007 Best Paper Award of the British Accounting Review for his paper "Loss firms' annual report narratives and share price anticipation of earnings' \& the prestigious 2012 Best Paper Award of the Journal of Risk Finance. He is currently the Editor-in-Chief of Journal of Financial Reporting and Accounting; an Associate Editor for Journal of Applied Accounting Research and International Journal of Accounting, Auditing and Performance Evaluation. khaled.hussainey@ port.ac.uk

Prof Hédi Noubbigh is an Associate Professor of Accounting, at IHEC Carthage, University of Carthage, Tunisia. He received his PhD from the FSEG Tunis, University of Tunis, Tunisia in 2006. He has published on Managerial Auditing Journal, Revue Française de Gestion, ect.. noubbigh.h@gmail.com 


\begin{abstract}
This study investigates the effect of positive states, perceived supervisor support and independence of internal audit function on internal auditors' moral courage. Although extensive research has suggested that risk of feared consequences is the major cause that inhibits internal auditors from reporting managerial fraud, there has been little empirical investigations into the way of fostering internal auditors' moral courage to speak up.

The present work used a survey of 146 internal auditors in Tunisia. The Partial Least SquareStructural Equation Model (PLS-SEM) was used to test our hypotheses.

The results indicate that self-efficacy, resilience, perceived supervisor support and the independence of internal audit function have a positive effect on the internal auditors' moral courage; however, state hope does not show a significant link. Additionally, we find that women experience higher levels of moral courage compared to men.
\end{abstract}




\section{Introduction}

Previous evidence has shown that internal auditors are more helpful in detecting fraud and corruption compared to external auditors (Halbouni, 2015; Jayalakshmy et al., 2005), nevertheless, they are still reluctant to report them. Accordingly, academicians and professionals describe them as 'gatekeepers' who failed to prevent the global financial scandals (Chambers and Odar, 2015).A growing body of research has revealed that the fear of retaliation is the main cause of the silence of non-reporting observers (Khelil et al., 2016; Cassematis and Wortley, 2013; James, 2003). Keil et al. (2010) note that retaliation is common and is reported to happen $17-38 \%$ of the time. It is manifested in several forms including job loss, intimidation, death threats, defamation of character and negative impact on one's career, all of which can exert a physical and psychological toll on the health of whistleblower (Comer and Schwartz, 2015; Miceli et al., 2008).

Moral courage is an attribute that motivates and enables individuals to take the right path of action based on the ethics of their professions (Sekerka et al., 2009).Morales-Sánchez and Cabello-Medina (2013) support this view by noting that prosocial behaviors, such as speaking up, require access to moral courage. Such courage is a moral competency that implies overcoming fear.

Despite the great agreement in the literature that internal auditors keep silent out of fear of reprisal, there have been few empirical investigations into the factors that enhance their moral courage to speak up when they encounter wrongdoings (e.g., Khelil et al., 2016; Khelil et al., 2017).Until now, however, auditing scholars have tended to focus on internal auditors' responsibilities in disclosing management fraud and have not considered what encourages them to exercise these responsibilities. Indeed, internal auditors need not only to know what the right thing to do is, but also to have the courage to do it (Khelil et al., 2016). 
We aimed to fill this gap by examining the effect of positive states (self-efficacy, state hope and resilience), internal auditor's independence and perceived supervisor support on internal auditors' moral courage to speak up when they encounter wrongdoings. Additionally, the examination of the Tunisian context makes a particular contribution to the internal auditing works related to the Middle East and North Africa (MENA), as little research has been conducted in this region (Al-Akra et al., 2016).

The choice of the Tunisian context is justified by these main reasons. First, although fraudulent deeds and malpractices continue to propagate in such a country (Hentati-Klila et al., 2016), too little attention has been paid to how to encourage auditors to report fraud.

Second, nowadays, the internal audit function (IAF) is depicted as part of the solution to perceived breakdowns in the systems of internal control, business reporting and ethical behavior (Bailey et al., 2003). Asiedu and Deffor (2017) assert that an effective internal audit function can reduce administrative corruption. Due to the growing importance of internal audit in ensuring corporate governance efficiency, the recent formal corporate governance guidance in Tunisia (code of best practices of corporate governance for Tunisian public enterprises, in 2008, updated twice in 2012 and in 2014) has strengthened the professional and ethical responsibilities of internal audit within public and private organizations. Accordingly, a research on what motivates Tunisian internal auditors to fulfill these responsibilities is required. Moreover, considering moral courage as a moral muscle that spurs the moral strength to face corruption (Sekerka, 2011), the investigation of the Tunisian context is timely as Tunisia is in the midst of a revolution at the social, economic and financial levels. Such a revolution aims to fight corruption (illegal acts, fraud, and unethical behaviors) and to promote integrity in both the private and the public sectors (Khelil et al., 2016).

For this study, 146 questionnaires were administered to Tunisian internal auditors and a Partial Least Square-Structural Equation Model (PLS-SEM) was used to test our hypotheses. 
Although the advantage of using structural equation modeling (SEM) has been widely explained in previous studies to analyze accounting behavioral data, SEM is still underutilized in accounting behavioral scholars compared to related disciplines such as psychology, management and information systems (Hampton, 2015). Accordingly, this study makes an original methodological contribution to the behavioral accounting literature.

Our results show that self-efficacy, resilience, perceived supervisor support, and the IAF independence have a positive effect on internal auditors' moral courage. However, state hope does not show a significant link with the moral courage of the internal auditor.

The paper is organized as follows. Section 2discusses the research background and reviews relevant literature. We develop our hypotheses in section 3and discuss the research methodology in section 4. The analysis and discussion of results are presented in section 5 . Section 6concludes the paper.

\section{Research Background and Relevant Literature}

\subsection{The Role of Internal Auditors in Fraud Reporting}

Resounding corporate scandals have generated so much public disappointment leading the internal auditing standard setters to seek ways to reinforce the internal auditors' will-power to strive corporate malfeasance and promote truthfulness by restoring a responsibility for fraud reporting not only internally but also externally.

The Institute of Internal Auditors (IIA, 2015) decrees in Standard 2060 that "the chief audit executive must report periodically to senior management and the board on the internal audit activity's purpose, authority, responsibility and performance relative to its plan. Reporting must also include significant risk exposures and control issues, including fraud risks, governance issues and other matters needed or requested by senior management and the board". 
Practice Advisory 2440-2 'Communicating Sensitive Information within and outside the Chain of Command' related to internal audit standard 2440explains that: in some situations, an internal auditor may face the dilemma of considering whether to communicate the information to persons outside the normal chain of command or even outside the organization. This communication is commonly referred to as "whistle-blowing." The act of disclosing adverse information to someone within the organization but outside the internal auditor's normal chain of command is considered as internal whistle-blowing while disclosing adverse information to a government agency or other authority outside the organization is considered to be external whistle-blowing

The aforementioned requirements are supported by the academicians who advocate that internal auditors are potential whistleblowers by reporting illegal activities within organizations to audit committees, boards of directors or government agencies (Miceli et al., 1991; Xu and Ziegenfuss, 2008).

In addition, and given the trust placed in the internal auditors to furnish accurate information on internal control, risk management systems and corporate governance processes, the IIA Code of Ethics (IIA, 2013) as well as the rules of conduct specify norms of behavior stressing a set of cardinal principles that internal auditors should uphold.

Noting that "the integrity of internal auditors establishes trust and thus provides the basis for reliance on their judgment, " the rules of conduct emphasize that internal auditors must execute their work with honesty, responsibility and diligence. Similarly, the internal auditors must make disclosures expected by law and within the profession.

An overwhelming body of research depicts speaking up about fraud as an ethical and prosocial behavior as it has several beneficial effects for organizations and for society at large (Harbour and Kisfalvi, 2014; Miceli et al., 2008).In this context, some authors use adjectives inspired from ethical and religious glossaries when describing the whistleblowers. Grant (2002) views 
them as 'Saints of Secular Culture' and Avakian and Roberts (2012) describe them as 'prophets'. According to Burke (2013), whistleblowers are 'people of conscience' who behave to spur human welfare.

\subsection{Internal Auditors' Moral courage and Fraud Reporting}

Despite the professional and ethical responsibility for fraud reporting, internal auditors still face ethical conflicts when the disclosure of audit findings can have deleterious effects on their careers (Khelil et al., 2016). In fact, internal auditors are related to management not as enablers but as individuals involved in the conflict. Independent auditor/corporate management conflicts involve two sources of power: the pecuniary temptations of management teams to induce auditors to sanction ignobility versus the integrity of auditors to resist such temptations (Bayou et al., 2011).

In this context, Osswald et al. (2012) contend that behaving ethically in the presence of power imbalances requires moral courage. Such a moral courage is defined as "the expression of personal views and values in the face of dissension and rejection" and in cases in which "an individual stands up to someone with power over him or her (e.g., boss) for the greater good" (Lopez et al., 2003, p. 187). Likewise, when we explicitly assess one's moral interest in a given situation, we find that he/she musters the moral courage to resist pressures to obey authorities (Skitka, 2012). Accordingly, moral courage actions serve "as a protection against obedience to potentially malevolent authorities or blind conformity to group norms" (Skitka, 2012, p 21). The importance of the moral courage for auditors has been theoretically and empirically recognized by academics and professionals. In their qualitative study, Libby and Thorne (2007) reveal that courage is an instrumental virtue that plays a significant role in enhancing the ethical judgment of auditors. Similarly, the role of moral courage in promoting the moral character of auditors is evident in the studies of Armstrong et al. (2003) and Khelil et al. (2016). These 
authors relied on Thorne's (1998) integrated model of ethical decision-making to show how moral courage can determine auditors' ability to behave in accordance with their ethical intentions.

The findings emerging from the exploratory study of Roussy (2012) provide a support for these views. Roussy (2012) reports that fourteen members of audit committee working in organizations of the Quebec public sector believe that courage is an essential value that internal auditors must have to discuss sensitive issues. Accordingly, the audit committee members expect that the internal auditors behave courageously to describe things as they are and thus to permit them to trust their work and the content of the audit reports.

The findings of Roussy (2012) are consistent with those of Everett and Tremblay (2014) who sought to identify the crucial virtues that motivate "Cynthia Cooper" (WorldCom's ex-Vice President) to behave ethically and to report fraud committed by her bosses. The examination of Cooper's autobiography permitted the authors to conclude that her ethical behavior was based on her courage and resilience in the face of threats.

\section{Development of Hypotheses}

There is a general agreement in the existing literature that moral courage is not an innate behavior but is tied to motivation and ready for development through internal and external resources (Khelil et al., 2016; Comer and Schwartz, 2015; Osswald et al., 2012; Hannah et al., 2010, 2013).

In what follows, we will show how positive states (self-efficacy, hope, resilience), perceived supervisor support together with the IAF independence can affect internal auditors' moral courage.

\subsection{Positive States}

Fredrickson et al. (2003) reveal that positive states construct personal resources to counteract narrowing of thought-action repertoires otherwise generated under stress. Similarly, Hannah et 
al. (2010) propose that positive states such as self-efficacy, hope, and resilience, if contained in a social role, play a critical role in enhancing courage when we face risks associated with this role.

\section{Self-efficacy}

Self-efficacy is a fundamental concept of social cognitive theory grounded by Bandura (1982, 1986). It is described as "an important determinant of how much effort people will exert and how long they will persevere in the face of significant challenges" (Rice, 1998, p. 540).In this manner, the perception of efficacy can foster motivation and performance in different ways. In fact, often related to confidence, self-efficacy is operationalized in terms of challenging self-set goals, generous effort, self-selection into difficult tasks, mobilization toward task mastery and goal achievement and perseverance when encountering obstacles (Goud, 2005; Youssef and Luthans, 2012).

The role of self-efficacy in enhancing moral courage and overcoming fear has been widely recognized in previous literature (Amos and Klimoski, 2014; Hannah et al., 2010; Sekerka and Bagozzi, 2007; Goud, 2005).

Based on the fact that a high level of self-efficacy fosters the individual's belief that he/she can influence the situation toward a necessary or a desired outcome, especially under risk, Amos and Klimoski (2014) highlight that confidence is a critical individual characteristic attached to behaving with courage. Indeed, an individual, who lacks a positive sense of self, is not expected to choose taking risks and to behave with courage.

According to Hannah et al. (2010), self-efficacy is obviously associated with envisioning successful outcomes (Bandura, 1997) and encouraging goal-directed acts. As result, individuals with high levels of self-efficacy experience less stress and perceptions of being threatened when encountering fearful situations; they try to persist despite being threatened. Goud (2005) 
supports this view by stating that "belief and trust in one's capabilities (i.e., confidence) is a primary force in countering fears, risks, and the safety impulse" (p. 110).

Sekerka and Bagozzi (2007) state that "the perception of one's power to act relies upon a belief that the individual has some control over the present circumstances" (p.137). Chemers et al. (2000) assert that this type of judgments boosts the desire to behave with moral courage. They claim that self-efficacy is critical to moral courage because these types of judgments affect "not only what skills people perceive themselves to have, but also what they believe they can do with the skills they possess", (p. 268).From this and based on social cognitive theory (Bandura, 1982), we derive our first hypothesis:

Hypothesis 1 (H1): The moral courage of the internal auditor is positively related to his/her self-efficacy.

\section{State hope}

According to Snyder et al. (1991), hope is defined as "a positive motivational state that is based on an interactively derived sense of successful (1) agency (goal-directed energy) and (2) pathways (planning to meet goals)" (p. 287).

Synder et al. (1996) explain that hope consists of two dimensions; agency and pathways. First, individuals behave on goals they set using their agency (motivation and drive). Second, pathways (several ways or paths) are created to attain these goals.

Building on the fact that hope is made up of "willpower (agency) and way power (alternate pathways)" (Peterson and Luthans, 2003, p.26), the literature on moral courage argues that hope provides the courageous actor with goal-directed energy and promotes envisioning different paths to success (Hannah et al., 2010; Sekerka and Bagozzi, 2007; Pury et al., 2007).

Based on the expectancy theory (Vroom, 1964) which posits that people frequently decide to act based on the probability of the desired outcome, Sekerka and Bagozzi (2007) affirm that the 
higher the outcome expectancies of success towards acts of moral courage, the greater the person's desire to behave courageously.

Likewise, Hannah et al. (2010) suggest that high levels of hope enhance the envisioning of extended thought repertoires (pathways) to attend to threats as well as the use of focused energy to implement solutions, which in turn decrease fear and spur courageous behaviors. Similarly, Pury et al. (2007) demonstrate that whatever the type of courage (personal or general), the higher the individual's judgment that the situation will ameliorate and the outcome will be successful, the more the individual is expected to be evaluated as courageous. From this and building on the expectancy theory (Vroom, 1964), we will examine the following hypothesis: Hypothesis 2 (H2): The moral courage of the internal auditor is positively related to his/her state hope

Repealing that state hope is made up of two dimensions (agency and pathways), Peterson and Luthans (2003) affirm that both dimensions are additive, iterative and positively related, but remain conceptually distinct constructs. Accordingly, it is not sufficient to have solely agency or pathways; both must be present. On this basis, two underlying hypotheses are relevant:

H2.a. The moral courage of the internal auditor is positively related to the agency dimension.

H2.b.The moral courage of the internal auditor is positively related to the pathway dimension.

\section{Resilience}

The positive psychology literature defines resilience as positive coping and adaptation in the face of significant risk or adversity (Luthans et al., 2007; Lee et al., 2012).

According to the American Psychological Association (APA), resilience is "the process of adapting well in the face of adversity, trauma, tragedy, threats or even significant sources of stress such as family and relationship problems, serious health problems or workplace and 
financial stressors". ${ }^{2}$ Applied to the workplace, Luthans (2002a) describes this state as the "positive psychological capacity to rebound; to 'bounce back' from adversity, uncertainty, conflict, failure, or even positive change, progress and increased responsibility” (p. 702).

Many studies suppose that highly resilient people tend to be more effective in various life experiences, encompassing adjustment and development under a variety of life-course threatening situations (Bergheim et al., 2015; Lee et al., 2012; Luthans et al., 2007).

According to Hannah et al. (2010), resilience is similar to coping efficacy, which is defined as the belief in one's ability to overcome negative cognitions and ruminative thought to succeed in a given challenge (Bandura,1989), such as a challenge requiring courageousness. In this manner, resilience is deemed as important for the activation of courage.

In the same vein, Bergheim et al. (2015) support that such state enables workers to feel at ease outside their habitual- comfort area and challenge personal assumptions and external obstacles. In their detailed examination of the autobiography of Cynthia Cooper (the ex-Vice President of Internal Audit at WorldCom), Everett and Tremblay (2014) attempt to identify the crucial practical virtues that led Cynthia Cooper to behave ethically by blowing the whistle. This heroic accountant showed her positive adaptation in the face of adversity, threats and risks. Indeed, she experienced serious consequences (including demoralization, loneliness, and humiliation) and several real physical costs (including sickness, loss of sleep, alcoholism and depression). Executives conspired against her and fellow employees became angry with her. She feared for her safety, family, home and savings while the case dragged on for years.

The findings of Everett and Tremblay (2014) are consistent with those of Khelil et al. (2017) who used thirty structured interviews with Tunisian chief audit executives to identify the factors that promote internal auditors' moral courage. There was a consensus among the interviewees 
that resilience is critical for the activation of courage. Accordingly, to be courageous; an internal auditor should be able to resist pressure, risk, threat and danger.

Based on the above discussion, the following hypothesis is developed:

Hypothesis 3 (H3): The moral courage of the internal auditor is positively related to his/her resilience.

\subsection{Perceived supervisor support}

Perceived organizational support (POS) is defined as workers' perceptions of "the extent to which the organization values their contributions and cares about their well-being" (Eisenberger et al., 1990, p.51).

The organizational support theory (Eisenberger et al., 1986) posits that the development of POS is promoted by employees' tendency to assign the humanlike characteristics to the organization. POS is valued as an assurance that aid will be provided by the organization when needed to cope with stressful situations and perform one's job effectively (Rhoades and Eisenberger, 2002). Moreover, it strengthens employees' identification and support for organizational goals and those that go beyond the call of normal duty (Alleyne et al., 2013).

Hannah et al. (2010) affirm that organizations enhance the activation of self-regulatory expectations and plan to engage in courageous behaviors by promoting perceptions of a supportive context (i.e. protecting whistle-blowers from punishment).

Because supervisors act as organizational agents, Rhoades and Eisenberger (2002) confirm that the employee's receipt of favorable treatment from a supervisor should contribute to POS. The strength of this relationship is associated with the degree to which employees identify the supervisor with the organization, as opposed to regarding the supervisor's actions as 
idiosyncratic. Likewise, Mayer et al. (2013) state that employees are expected to look to the support of supervisors when faced with uncertainty about whether to engage in a risky behavior.

Alleyne et al. (2013) highlight that the concept of POS is consistent with social exchange theory (Blau, 1964) and the norm of reciprocity (Gouldner, 1960).Indeed, the relationship between supervisors and subordinates is based on social exchange, wherein "each party must offer something the other party sees as valuable and each party must see the exchange as reasonably equitable or fair" (Graenand Scandura, 1987, p. 182).

In this sense, Alleyne et al. (2013)clarify that auditors are more likely to feel committed to his/her organization when he/she perceives a great level of organizational support. Accordingly, the auditor will feel comfortable reporting unethical deeds. In other words, the courage to speak up is based on the auditor' perception of organizational support.

In the internal audit context, several studies describe the audit committee as an organizational agent that provides support for the internal auditor (Khelil et al., 2016; Sarens et al., 2009; Turley Zaman, 2007). Indeed, an internal audit function which is strongly supported by the audit committee is likely to be more objective and powerful in the implementation of control (Khelil et al., 2016; Mat Zain et al., 2006).

Considering the audit committee as a critical vehicle in increasing the organizational status of internal auditing (Scarbrough et al., 1998), an audit committee should reinforce the position of the internal audit function by offering a supportive environment where the chief audit executive (CAE) can raise matters affecting his/her manager (Khelil et al.,2016; Alzeban, 2015; Zaman and Sarens, 2013). The Organization for Economic Cooperation and Development (OECD 2014) supports this view in its report "Use the audit as risk management tool in the Tunisian public sector" by noting that the audit committee is able to provide additional support to ensure the effectiveness and independence of internal audit activities. 
Supporting that audit committees act as agents of the organization and are responsible for guiding and assessing internal auditors' performance (Khelil et al., 2016;Alzeban, 2015), we believe that internal auditors view their audit committees' favorable or unfavorable orientation toward them as a signal of the organization's support. Building on organizational support theory (Eisenberger et al., 1986) and social exchange theory (Blau, 1964), we assume that it is on the basis of their perceptions that internal auditors make decisions to report fraud and irregularities or to keep silent.

From this, we hypothesize that:

Hypothesis 4 (H4): The moral courage of the internal auditor is positively related to his/her perception of the audit committee support.

\subsection{Independence of the internal auditing function}

Independence is described as "the freedom from conditions that threaten the ability of the internal audit activity to carry out internal audit responsibilities in an unbiased manner" (IAASB, 2013). Auditor independence has been recognized as crucial for the auditing profession (Arya and Glover, 2014). Indeed, recent evidence shows that the quality of audit and financial reporting depends on auditor independence (Du et al., 2015).In this sense, several attribute standards and associated practice advisories have been publicized by the IIA focusing on internal auditors' independence. According to standard 1100 "internal audit activity must be independent, and internal auditors must be objective in performing their work" (IIA, 2009). In other words, independence is framed as the means that protects internal auditors against conflict of interest, bias or influence of others that would offend their professional judgments (Abbott et al., 2016).

Given that internal auditor can experience familiarity and threats of social pressure generated from their relationships with managers (Khelil et al., 2016), the aforementioned Standard 
stresses the fact that 'the chief audit executive should report to a level within the organization that allows the internal audit activity to fulfill its responsibilities'.

Abbott et al. (2016) explain that the internal audit function should be shielded from managerial pressures, because the manager can reduce the likelihood of reporting issues and fraud to the proper channel. In this context, both external and internal auditing standards and professional best practices emphasize that internal auditor's objectivity is promoted when the oversight of the internal audit function by the audit committee is greater than the managerial oversight (IIA, 2002; AICPA, 2013; Abbott et al., 2012). Therefore, the independence of the internal auditor is a direct function of the reporting relationship between the audit committee and the internal audit function.

In parallel, a considerable amount of literature has supported an association between greater audit committee oversight and greater independence for the internal audit function (Abbott et al., 2012, 2016; Alzeban, 2015; Goodwin and Yeo, 2001) as the former permits shielding auditors from possible managerial pressure (Abbott et al., 2012, 2015).

James (2003) proves that internal auditors related to the audit committee are viewed as more likely to report fraud than those related to senior management.

In the same vein, Goodwin and Yeo (2001) assert that establishing a direct reporting relationship between internal auditors and the audit committee can strengthen the position of internal auditors' function and boost their independence. In fact, the audit committee behaves as an independent forum for the internal auditor to report critical problems that affect his/her manager. Stewart and Subramaniam (2010) add that the audit committee can create a "tone" permitting internal auditors to have a degree of influence and power in their organizations. Furthermore, Alzeban (2015) claims that hiring and firing the CA which is a significant responsibility arising out of this reporting relationship can affect internal auditors' independence. He argues that hiring/firing decisions should be made without managerial 
influence to ensure the impartiality of internal auditor so that they report poor managerial deeds without a fear of reprisals.

Khelil et al. (2016) assert that the organizational position of the internal audit function permits to enhance its effectiveness by fostering the chief audit executive's courage. They find that the participation of audit committee in CAE hiring/firing decisions might not promote the chief audit executive's moral courage. Khelil et al. (2016) performed complementary interviews with 22 CAEs to explain this finding. The interviewees explain that it is insufficient for the audit committee to be merely involved in such decisions; instead, the committee should make the final decision. For that reason, the audit committee must have full authority concerning the career of the CAE to guarantee his/her independence and then to foster his/her courage.

In addition to reporting lines and termination rights, Abbott et al. $(2012,2016)$ consider that budgetary control performed by the audit committee is a third critical facet of the independence of internal audit activity.

Hence, the independence of internal auditors is determined by the audit committee oversight of internal audit activity (reporting lines, termination rights and budgetary control). Thus, Hypothesis 5 (H5): The moral courage of the internal auditor is positively related to the independence of internal audit function.

Figure 1 provides an overview of the proposed theoretical model concerning the effects of selfefficacy, hope (agency and pathway), and resilience, perceived supervisor support and IA independence on internal auditors' moral courage.

\section{Insert Figure 1 about here}

\section{Research Method}

\subsection{Sample Selection and Data Collection}


The data was gathered from Tunisian firms which have an internal audit function and an audit committee. Given that internal audit team is composed of an average of three internal auditors in each target company, three copies of the questionnaire were administered (face to face and electronically) to 77 listed companies and 4 non-listed companies in both financial and nonfinancial sectors. We did not exclude companies operating in the financial sector as fraud is a costly crime for all companies, regardless of their size and the industry in which they operate (Halbouni, 2015).The final target sample comprised 213 potential respondents

The questionnaire was in two parts. The first part intended to capture respondents' basic demographic information. This information included gender, age, training level, work experience and professional certifications.

The second part was dedicated to measure the level of internal auditors' moral courage, state hope, resilience, perceived supervisor support, self-efficacy and the independence of internal audit function (see appendix).

Data collection lasted nine months. It allowed us to receive, out of the 213 distributed questionnaires, 146 answers (68\%) from internal auditors working in financial and nonfinancial sectors.

As shown in table 1, our sample consisted of 57 internal auditors working in financial sector and 89 working in non-financial sector. The overwhelming majority of them (95\%) exercise in listed companies. The respondents include 94 men and 52 women with an average age of 38.16. The participants had between 2 and 30 years of professional experience. In addition, we document that more than half of respondents $(58 \%)$ had a Bachelor degree +5 or 6 . Responses also indicated that the certification was rare among internal auditors; only $8 \%$ of participants had at least an international certification related to internal auditing (CISA, CIA, or DPAI).

Insert Table 1 about here

\subsection{Variable Measurement}




\section{Dependent variable}

Moral courage: was assessed with a four-item moral courage scale developed by Hannah and Avolio (2010), which has demonstrated high reliability and construct validity in earlier studies (Hannah et al., 2013; 2011; Schaubroeck et al., 2012; 2010).

Participants rated their levels of moral courage on a Likert scale ranging from 1 (strongly disagree) to 5 (fully agree). To contextualize the measure, the instructions directed participants to "think about your actions while you detect a fraud occurred by your manager and rate your level of agreement with how each item applies to you."

\section{Independent variables}

Self-efficacy: was measured with the ten-item Self-efficacy scale developed by Parker (1998) building on Bandura (1986). This scale is the most used among organizational literature. It demonstrated high reliability and constructed validity in earlier studies (Bergheim et al., 2015; May et al., 2014; Luthans et al., 2007a, 2008b, and 2007c).

The respondents were asked to rate how confident they would feel if they were asked to carry out each of the 10 tasks using a 5-point Likert scale from 1 (not at all confident) to 5 (very confident).

State hope: The state hope measure used in the study was developed by Snyder et al. (1996). This scale has been widely used in workplace context (Peterson and Luthans, 2003; Luthans et al., 2007a, 2008b, 2007c; Bergheim et al., 2015). This six-item scalehas undergone rigorous psychometric analyses concerning internal and temporal consistency. It comprises two identifiable and robust agency and pathwaysfactors (Snyder et al., 1996; Peterson and Luthans, 2003). In other words, the agency (the evenly-numbered items) and pathways (the oddnumbered items) are subscales which are factorially identifiable as subcomponents of the overall measure (Snyder et al., 1996). 
The six items use a 5-point Likert scale from 1 (strongly disagree) to 5 (fully agree) and instruct the respondent to answer how they think about themselves right now.

Resilience: The resilience measure comes from the widely recognized work of Block and Kremen (1996), who developed a self-report scale (the ER89) that permits the measurement of ego-resiliency by subjective self-ratings. The fourteen-item resilience scale (the ER89) has been the subject of different investigations. A first series of studies tested the psychometric properties of the ER89 using exploratory factor analysis and investigated correlations of the individual's mean score on the instrument with different relevant psychological components. The studies of Caprara et al. (2003), Letzrin et al., (2005) and Fonzi and Menesini (2005) corroborate the unidimensionality, internal consistency and reliability and construct validity of the scale.

The measure uses a 5-point Likert scale from 1 (strongly disagree) to 5 (fully agree).

Perceived supervisor support (PSS): it was measured as in several studies (Hutchison, 1997; Rhoades et al., 2001; Eisenberger et al., 2002; Shanock and Eisenberger, 2006; DeConinck, 2010) by replacing the term organization with the term supervisor in Survey of Perceived Organizational Support (SPOS) developed by Eisenberger et al. (1986).

Because of the high internal reliability reported for the Survey of Perceived Organizational Support (Eisenberger et al., 1990, 1986), Eisenberger et al. (2002) noted that a short form of SPOS, which includes the eight high-loading (Items 4, 8, 9, 13, 20, 22, 23, and 25) of the 36 items, can be used and therefore adapted to measure Perceived supervisor support.

These 8 items were retained in our study to assess the Perceived audit committee support. Respondents indicated the extent of their agreement with each item on a 5- point Likert-type scale from 1 (strongly disagree) to 5 (fully agree).

IAF Independence: Following Abbott et al. (2016; 2012) we measured the organizational independence of the internal auditing function by measuring audit committee's IAF influence vis-a-vis management's IAF influence based on three critical facets of the internal audit/audit 
committee relationship: reporting lines, termination rights and budgetary control. To capture the relative degrees of oversight, we asked internal auditors to state their level of agreement concerning the amount of influence exhibited by the audit committee versus management (CEO and CFO) on these three facets. The level of agreement ranged from 1 (strongly disagree) to 5 (strongly agree $)^{2}$.

\section{Control variables}

Based on business ethics and internal audit literature, certain control variables were considered in our empirical model: gender, age and activity sector. Although, to date, there have been mixed findings concerning the direction of the relationships between these variables and the ethical behavior(Cassematis and Wortley, 2013; Curtis et al., 2012; Liyanarachchi and Adler, 2011; Keenan, 2000;Miceli and Near, 1988), any possible effect of these factors was examined in the current study.

\subsection{Partial Least Squares (PLS) Regression}

Partial Least Square-Structural Equation Model (PLS-SEM) was used to test the research model and hypotheses. Partial Least Square (PLS) is a component-based structural equation modeling technique that simultaneously tests the psychometric properties of the scales used to measure the constructs (i.e., measurement model) and verifies the strength of the relations between the constructs (i.e., structural model) (Chin, 1998).

We chose the PLS for this study because it is suitable when there is a deficiency of previous theoretical knowledge, and/or when the size of the sample is relatively small (Lisi, 2016; Hair et al., 2014; Chin and Newsted, 1999). In addition, it develops minimal data suppositions as it does not need multivariate normal data (Lisi, 2016; Chin, 1998). According to Sosik et al. 
(2009), PLS most frequently generates better results because it uses a model for both the dependent and predictor data that account appropriately for the correlation structure of the data.

\section{Data Analysis and Results}

\subsection{Descriptive statistics}

Table 2 reports the descriptive statistics. It indicates that apart from perceived supervisor support, the actual range of the other variables was comparable with the theoretical range. The mean scores of moral courage (3.955), resilience (3.648), and perceived supervisor support (3.811) and self-efficacy (4.009) are greater than the midpoint of the average. Concerning state hope, the pathway (4.187) provides a mean score higher than that of the agency (3.887).The mean score of IAF independence (0.137) indicates that the amount of influence exhibited by the management (CEO and $\mathrm{CFO}$ ) (on reporting lines, termination rights and budget determination) is higher than this exhibited by the audit committee.

Insert Table 2 about here

\subsection{Measurement Model Analysis}

The measurement model in PLS is evaluated in terms of indicator reliability, internal consistency reliability, convergent validity and discriminant validity (Lisi, 2016; Hair et al. 2014).

As a first step before running PLS-SEM, and following Hair et al. (2014) as well as Hampton (2015), 19 outliers identified by Mahalanobis Distance ( $\mathrm{D}^{2} \mathrm{p} \_$value $\left.<0.001\right)$ were removed. Accordingly, the test of reliability was carried out on 127 answers.

The reliability test of the measurement model was performed in terms of indicator reliability and internal consistency reliability. Indicator reliability was assessed using the factor loading. Following the recommendations of Hair et al. (2014), an item (Hop5) which had very low factor loading $(<0.4)$ was deleted from the hope scale and the model was re-estimated. Then, 3 items (HOP1, HOP2, HOP6) which had factor loadings between 0.4 and 0.7 were dropped 
sequentially to ensure an internal consistency reliability (composite reliability $>0.7$ ) and a convergent validity (AVE >0.5). To comply with the common rule of thumb that dictates keeping items with factor loading greater than 0.7 (Hajli and Lin 2016; Hair et al. 2011), we deleted 6 items from the resilience scale (RES1, RES2, RES5, RES6, RES9, and RES10). Table 3 presents the item loadings from both the initial and the final PLS measurement model. It shows that all the factor loadings are greater than 0.7 in the final model. In addition, the table indicates a satisfactory reliability of the constructs, given that all composite reliability (CRs) exceeds 0.7 (Lisi, 2016; Hajli and Lin, 2016; Hair et al. 2014; Hulland 1999). The Cronbach's alpha values support the constructs' reliability (Cronbach's alpha $>0.6$ ) (Murphy and Davidshofer, 1988).

The examination of the average variance extracted (AVE), which permits to assess the convergent validity of constructs, demonstrates an adequate convergent validity. Indeed, the AVE for each variable is greater than 0.50 (Hair et al. 2014; Lisi, 2016).

Insert Table 3 about here

We finished with assessing the discriminant validity, which presents the extent to which the measures of a given construct diverges from other constructs' measures in the same model (Hulland, 1999). In other words, the discriminant validity is satisfied only when the square roots AVEs are all higher than the respective correlations between constructs (Hajli and Lin, 2016; Lisi, 2016; Hair et al. 2014). We found that the terms of discriminant validity were not fulfilled. The elimination of items (COURAGE2, COURAGE3, COURAGE4, PSS1, PSS3, PSS8, RES11, S_EFF2, S_EFF4, S_EFF5, S_EFF6, S_EFF8) having outer variance inflation factor (VIF) value greater than 5 (Hair et al. 2011) did not resolve the problem. Self-efficacy and perceived supervisor support were highly correlated (table 4).

Insert Table 4 about here 
In order to mitigate this situation, we estimated two measurement model versions (Akrout, 2016). The first model considered the perceived supervisor support and did not consider selfefficacy, while the second model considered self-efficacy and did not consider the perceived supervisor support. As we did in the beginning, we removed 2 and 3 outliers (identified by Mahalanobis Distance; $\mathrm{D}^{2}$ p_value $<0.001$ ) in the first and second measurement model versions, respectively. The results show an adequate reliability and validity for each construct in the two measurement model versions (tables 5 and 6). This allows us to interpret the structural model for these two versions.

\section{Insert Tables $5 \& 6$ about here}

\subsection{Structural Model Analysis: Test of Hypotheses}

In this part, we seek to test the extent to which independence, hope (agency and pathway), resilience, perceived supervisor support and self-efficacy influence internal auditors' moral courage. To this end, a PLS-SEM was used to test the proposed hypotheses in which moral courage was the predictive variable (figure2).

\section{Insert Figure 2 about here}

The principal assessment criteria for the structural model are the measures of $\mathrm{R}^{2}$ and the level of significance of the path coefficients. Hair et al. (2011) clarify that the main target constructs' level of $\mathrm{R}^{2}$ should be high because the goal of the prediction-oriented PLS-SEM approach is to explain the variance of the endogenous latent variables.

In addition, PLS produces standardized path coefficients or $\beta$-statistics for each path coefficient (Lisi, 2016). Standardized path coefficients, t-statistics and $\mathrm{R}^{2}$ for the two models are shown in tables 7 and 8 and, graphically, in figure 2.

As reported respectively in the two tables, the two models have good predictive capabilities $\mathrm{R}^{2}=0.711$ in the first model and $\mathrm{R}^{2}=0.694$ in the second one. The coefficient for three out of five hypothesized paths in each model are statistically significant $(\mathrm{p}<0.05)$. 
Regarding self-efficacy, the findings reported in table 8 indicate that the self-efficacy of internal auditor has a positive significant effect on his/her moral courage $(\mathrm{p}=0.000<0.05)$. Such findings provide a strong support for $\mathrm{H} 1$ and confirm the suggestions of Hannah et al. (2010) as well Sekerka and Bagozzi (2007) who believe that self-efficacy makes an important contribution to the desire to act with moral courage. Similarly, our findings are consistent with Goud (2005) and Amos and Klimoski, 2014 who claim that doing what is right in the face of fear requires a great amount of confidence.

As can be observed in these two tables, the path between the agency and moral courage as well as the path between the pathway and moral courage are statistically insignificant in the two models ( $\mathrm{p}>0.05$ ). Accordingly, $\mathrm{H} 2 \mathrm{a}$ and $\mathrm{H} 2 \mathrm{~b}$ are rejected. These results indicate that the state hope does not have a significant effect on internal auditors' moral courage. Our results are inconsistent with the previous literature (Hannah et al., 2010; Sekerka and Bagozzi, 2007; Goud 2005) which suggest that increased levels of hope permit decreasing fear and spur courageous action. Similarly, our findings diverge from those ofPury et al. (2007) who found, in the American context, that the greater the participant's judgment that the situation will improve and the outcome will be successful, the more likely the participant is to be assessed as courageous. Our findings demonstrate that moral courage of internal auditors in Tunisia does not depend on their perceptions of their environment and the expectations they draw up based on these perceptions. We can explain this by the fact that the Tunisian context does not provide a motivational environment to internal auditors. Indeed, there is no law that protects the internal auditor in Tunisia. Additionally, we should note that Tunisia is classified among countries with an imperfect democracy (democracy score in $2015=6.72)^{3}$. This can explain the divergence of our findings from those of Pury et al. (2007) who conducted their study in the USA which is a fully democratic country (democracy score in $2015=8.05$ ). 
Tables 7 and 8 also indicate that resilience has a positive significant effect on internal auditors' moral courage in both models since the path between resilience and internal auditors' moral courage is positive and significant $(\mathrm{p}<0.05)$. Accordingly, $\mathrm{H} 3$ is supported.

These findings are consistent with the propositions of Hannah et al. (2010) and Lee et al. (2012), according to whom the positive adaptation in the face of adversity, threats and risks are important for the activation of courage. Additionally, our results confirm those of Everett and Tremblay (2014) who find that the courageous behavior of Cynthia Cooper was enhanced due to her resilience and her adaptation capacities in the face of serious risks and threats. According to Khelil et al. (2017), the internal audit activity, in Tunisian firms, is very damaging and tiring for an internal auditor who wants to work in an ethical manner respecting the standards and rules. In this sense, the internal auditor must resist by holding his/her ground with respect to moral matters even if he/she is opposing social pressures, and must therefore behave ethically whatever will happen.

Regarding the effect of perceived supervisor support on internal auditors' moral courage, the results reported in Table 7 furnish a strong support for the proposed hypothesis H4. Indeed, the direct path between perceived supervisor support and moral courage is positive and significant $(\mathrm{p}=0.000<0.05)$. These results support the proposition of Hannah et al. (2010) who affirm that organizations can increase the activation of self-regulatory plans and expectations that individuals will engage in courageous behaviors by enhancing perceptions of a supportive context. Similarly, our findings go along with those of Alleyne et al. (2013) who believe that auditors feel comfortable and courageous reporting unethical acts when they perceive their supervisors' support.

The results emerging from the analysis of both models indicate that the independence of internal audit function has a positive and significant effect on internal auditors' moral courage $(\mathrm{p}<0.05)$. Such results provide strong support for H5 and confirm the view of Khelil et al. (2016). 
According to Khelil et al. (2016), the independence of IAF which is ensured by the audit committee fosters the moral courage among internal auditors enabling them to speak up about managerial wrongdoings. Similarly, these results are consistent with those of James (2003) who reveals that internal auditors that report solely to the audit committee are more capable of preventing fraudulent reporting compared with auditors that report to senior management.

This can be explained by the idea of Abbott et al. (2016) who clarifies that a greater audit committee oversight of internal audit activity is associated with greater shielding from possible managerial pressure.

Additionally, these results confirm the pertinence of the international institutes' requirements of reporting directly and solely to the audit committee (Institute of Internal Auditors [IIA], 2009).

The results of the integration of the control variables in the two models using PLS show that the age of internal auditors has no significant effect on moral courage of internal auditors in both models ( $p>0.05)$. Such results diverge from those found by Near and Miceli (1996), Keenan (2000) as well as Liyanarachchi and Adler (2011) who reveal that older employees are more likely to report wrongdoing. However, our results are in agreement with those of Cassematis and Wortley (2013) who did not find a significant relationship between age and reporting wrongdoings.

Our findings also indicate that the activity sector does not show a significant effect on internal auditors' moral courage ( $\mathrm{p}>0.05)$ in both models. These results do not confirm our expectation that being supervised by a regulatory body, such the Central Bank, allows increasing the responsibility of internal auditors for reporting each irregularity and the disclosure of truthful financial statements.

Insert Tables $7 \& 8$ about here 
Table 9 shows that gender has a significant effect on internal auditors' moral courage in the two models $(\mathrm{p}<0.05)$. We find that females experienced higher levels of moral courage compared to males. These results are consistent with those of Cohen et al. (1998) and Borkowski and Ugras (1998) who find that females maintain a higher degree of concern for obligation and duty than males and then display more ethical behavior. However, our findings diverge from data from previous studies (Miceli and Near, 1988; Liyanarachchi and Adler, 2011) which demonstrate that women are less likely than men to report wrongdoings because they are more reluctant to risk their careers (Liyanarachchi and Adler, 2011).

Insert Table 9 about here

\section{Conclusion}

Based on 146 questionnaires gathered from Tunisian internal auditors and using the Partial Least Square-Structural Equation Model (PLS-SEM), this manuscript offers empirical evidence about the effects of positive states (self-efficacy, state hope and resilience), the perceived supervisor support and the independence of internal audit function on internal auditors' moral courage. Demographic variables such as gender, age and activity sector were also considered in our empirical model as control variables.

The present study makes several noteworthy contributions to internal audit and moral courage literature. It fills one of the major research gaps in these streams of research by demonstrating that the courageous behavior of internal auditors can be fostered by internal resources such as self-efficacy and resilience. Similarly, external resources such as the audit committee support and IAF independence are revealed as significant factors enabling internal auditors to behave courageously. Additionally, our research demonstrates that females experienced higher levels of moral courage compared to males.

We should note that concerning the IAF independence measure, prior internal audit literature often uses a dichotomous, single-variable measure and then it implicitly ignores other potential 
independence determinants (e.g., Khelil et al., 2016). To address this gap, we relied on three critical determinants of IAF independence (reporting lines, termination rights and budgetary control) defined in the studies of Abbott $(2012,2016)$.

Furthermore, the use of structural equation modeling (SEM) in this study presents a methodological contribution to auditing and accounting behavioral research as it remains underutilized in these fields compared to related disciplines such as psychology, management and information systems (Hampton, 2015).

Given the critical role moral courage plays in enhancing the ethical behaviors of the internal auditors, we believe that our findings carry implications for the understanding of the factors fostering internal auditors' moral courage to speak up when they encounter wrongdoings.

According to Sekerka et al. (2009), "if we hope to reach the highest levels of organizational performance, we must understand the factors that foster people's abilities to respond to challenges with courage" (p.575). We, firstly, contend that our results can provide practical solutions to foster internal auditors' moral courage to speak up so that a high level of organizational performance can be maintained.

Secondly, bearing in mind that Tunisia is adopting an approach to promote good corporate governance, revealing what motivates internal auditors to break their silence and behave courageously can help achieve this goal. Indeed, auditing literature suggests that an ethical and objective internal audit function can improve corporate governance by deterring employee theft and reporting financial irregularities as well as enhancing firm performance (Gramling et al., 2004).Asiedu and Deffor (2017) go further to say that an effective internal audit function helps reduce administrative corruption.

Moreover, our paper permits increasing the awareness of the Institute of Internal Auditors [IIA] about the necessity to consider certain positive traits that the internal auditors must have to 
behave ethically. Indeed, it is insufficient to focus only on ethics of auditing and imposing compliance controls.

The role of the audit committee in supporting and ensuring the internal auditors' independence was evident in our findings. Accordingly, our study can provide practical solutions to professional organizations and institutions (e.g. the Institute of Internal Auditors [IIA]) that seek to identify what might motivate internal auditors to courageously report corruption. We believe that our findings initiate them into the necessity of providing a supportive context for internal auditors and caring about their independence. Hence, regulators and standard setters are required to draft regulations and oversee the relationship between audit committees and the IAF to decrease the pressure exerted by the manager and thus reduce the fear of reprisals or threats of dismissal when reporting accurate information.

A limitation of this study is that the internal resources (self-efficacy, resilience and hope) rely on self-report measures that can induce a bias because of the respondents' desire for social acceptance.

Recognizing that both moral courage (Harbour and Kisfalvi, 2014)and internal auditing activity(Alzeban, 2015) involve normative elements and cultural differences, our study opens the door to further experimental investigations to examine the effect of positive states (selfefficacy, state hope and resilience), perceived supervisor support and the independence of internal audit function on internal auditors' moral courage in cultures different from the Tunisian one and thus permitting to compare the findings emerging from different contexts.

The effects of state hope on internal auditors' moral courage in the Tunisian context will be studied in a future work (when a new law will be implemented to protect internal auditors or when the score of democracy will improve).

Finally, further research should be conducted to investigate the effect of other internal and external resources (e.g., inner convictions, positive traits, social identity and group norms). 


\section{Notes}

1 American Psychological Association, The Road to Resilience, http://www.apa.org/helpcenter/roadresilience.aspx.

${ }^{2}$ Following Abbott et al. (2012, 2016) survey responses to questions \#2a-2iwererecalibrated to a scale of $0-4$. IAF Independence is a continuous variable defined as the sum of the three Likertscale responses to the three audit committee-IAF-statements $(2 \mathrm{a}, 2 \mathrm{~d}, 2 \mathrm{~g})$ divided by the sum of all nine Likert-scale responses concerning IAF/CEO/CFO/audit committee relationships per survey questions $2 \mathrm{a}-2 \mathrm{i}$.

${ }^{3}$ Source:

https://fr.m.wikipedia.org/wiki/Indice de d\%C3\%A9mocratie\#Indice de d.C3.A9mocratie_par_pays 2014.5B 8.5D_et 2015.5B9.5D

\section{References}

Abbott, L. J., Daugherty, B., Parker, S., \& Peters, G. F. (2016). Internal audit quality and financial reporting quality: The joint importance of independence and competence. Journal of Accounting Research, 54(1), 3-40.

Abbott, L. J., Parker, S., \& Peters, G. F. (2012). Audit Fee Reductions from Internal AuditProvided Assistance: The Incremental Impact of Internal Audit Characteristics. Contemporary Accounting Research. 29: 94-118.

Akrout, O. (2016). Intention de quitter la profession d'expertise comptable en Tunisie: acuité, déterminants et profils. Dotoral thesis, Carthage University.

Alleyne, P., Hudaib, M., \& Pike, R. (2013). Towards a conceptual model of whistle-blowing intentions among external auditors. The British Accounting Review, 45(1), 10-23.

Alzeban, A. (2015). Influence of audit committees on internal audit conformance with internal audit standards. Managerial Auditing Journal, 30 (6/7), 539-559.

American Institute of Certified Public Accountants (AICPA). AU Section 322: SAS No. 65 - The Auditor's Consideration of the Internal Audit Function in an Audit of Financial Statements. New York, NY: AICPA, 1991.

Amos, B., \&Klimoski, R. J. (2014). Courage Making Teamwork Work Well.Group\& Organization Management, 39(1), 110-128.

Ashforth, B. E., \&Anand, V. (2003). The normalization of corruption in organizations. Research in Organizational Behavior, 25, 1-52.

Asiedu, K. F., \&Deffor, E. W. (2017). Fighting Corruption by Means of Effective Internal Audit Function: Evidence from the Ghanaian Public Sector. International Journal of Auditing, forthcoming.

Bailey, A.D., Gramling, Jr., A.A., \& Ramamootri, S., editors. (2003). Research Opportunities in Internal Auditing. Altamonte Springs, Fl: Institute of Internal Auditors Research Foundation. 
Bandura, A. (1982). Self-efficacy mechanism in human agency. American Psychologist, 37, $122-147$.

Bandura, A. (1986). Social foundations of thought and action. Englewood Cliffs, NJ: Prentice-Hall.

Bandura, A. (1997). Self-efficacy: The exercise of control. New York, NY: Freeman.

Bergheim, K., Nielsen, M. B., Mearns, K., \& Eid, J. (2015). The relationship between psychological capital, job satisfaction, and safety perceptions in the maritime industry. Safety science, 74, 27-36.

Blau, P. M. (1964). Exchange and power in social life. New York, NY: Wiley.

Block, J. and Kremen, A. M. (1996). IQ and ego-resiliency: Conceptual and empirical connections and separateness. Journal of Personality and Social Psychology, 70, 349-61.

Borkowski, S. C., \& Y. J. Ugras. 1998. Business students and ethics: A meta-analysis. Journal of Business Ethics, 17: 1117-1127.

Brislin, R. W. (1980). Translation and content analysis of oral and written material. In H. C. Triandis\& J. W. Berry (Eds.), Handbook of cross cultural psychology (pp. 398-444). Boston: Allyn \& Bacon.

Cassematis, P. G., \& Wortley, R. (2013). Prediction of whistleblowing or non-reporting observation: The role of personal and situational factors. Journal of business ethics, 117(3), 615-634.

Caprara, M. G., Steca, P., \& De Leo, G. (2003). La misuradell'ego-resiliency [Egoresiliency measurement]. Ricerche di Psicologia, 26, 7-23.

Chambers, A. D., \&Odar, M. (2015). A new vision for internal audit. Managerial Auditing Journal, 30, (1), 34-55.

Cohen, J. R., L. W. Pant, \& D. J. Sharp. 1998. The effect of gender and academic discipline diversity on the ethical evaluations, ethical intentions and ethical orientation of potential public accounting recruits. Accounting Horizons, 12 (3): 250-270.

Chemers, M.M., Watson, C.B. \& May, S.T. (2000). Dispositional affect and leadership effectiveness: a comparison of self-esteem, optimism, and efficacy. Personality and Social Psychology Bulletin, 26 (3), 267-277.

Chin, W. W. (1998). The partial least squares approach to structural equation modeling. In G. A. Marcoulides (Ed.), Research methods for business research (pp. 295-336). Mahwah, NJ: Lawrence Erlbaum.

Chin, W. W., \&Newsted, P. R. (1999). Structural equation modeling analysis with small samples using partial least squares. In R. H. Hoyle (Ed.), Statistical strategies for small sample research (pp. 307-341). Thousand Oaks, CA: Sage. 
Comer, D. R., \& Schwartz, M. (2015) Highlighting Moral Courage in the Business Ethics Course. Journal of Business Ethics, 1-21.

Curtis, M. B., Conover, T. L., \&Chui, L. C. (2012). A cross-cultural study of the influence of country of origin, justice, power distance, and gender on ethical decision making. Journal of International Accounting Research, 11(1), 5-34.

DeConinck, J.B. (2010). The effect of organizational justice, perceived organizational support and perceived supervisor support on marketing employees' level of trust. Journal of Business Research, 63, 1349-55.

Eisenberger, R., Fasolo, P. M., \& Davis-LaMastro, V. (1990). Effects of perceived organizational support on employee diligence, commitment and innovation. Journal of Applied Psychology, 75(1), 51-59.

Eisenberger, R., Huntington, R., Hutchison, S., \&Sowa, D. (1986). Perceived organizational support. Journal of Applied Psychology, 71, 500-507.

Eisenberger, R., Stinglhamber, F., Vandenberghe, C., Sucharski, I. L., \&Rhoades, L. (2002). Perceived supervisor support: contributions to perceived organizational support and employee retention. Journal of applied psychology, 87(3), 565.

Everett, J. \& Tremblay, M.S. (2014). Ethics and internal audit: moral will and moral skill in a heteronomous field. Critical Perspectives on Accounting, 25(3): 1-16.

Fonzi, A., \&Menesini, E. (2005). Strategie di coping e caratteristiche di resilienza in adolescenza. PsicologiaClinicadelloSviluppo, 3, 437-456.

Fredrickson, B. L., Tugade, M. M., Waugh, C. E., \& Larkin, G. R. (2003). What good are positive emotions in crisis: A prospective study on resilience and emotions following the terrorist attacks on the United States on September 11th, 2001? Journal of Personality and Social Psychology, 84, 365-376.

Gino, F., Bazerman, M. H. (2009). When misconduct goes unnoticed: The acceptability of gradual erosion in others' unethical behavior. Journal of experimental Social psychology, 45(4), 708-719.

Goodwin, J., \& Yeo, T. Y. (2001). Two factors affecting internal audit independence and objectivity: Evidence from Singapore. International Journal of Auditing, 5(2), 107-125.

Goud, N. H. (2005). Courage: Its nature and development. The Journal of Humanistic Counseling, Education and Development, 44, 102-116.

Gouldner, A. W. (1960). The norm of reciprocity: a preliminary statement. American Sociological Review, 25(2), 161-178.

Graen, G. B., \&Scandura, T. A. (1987). Toward a psychology of dyadic organizing. Research in Organizational Behavior, 9, 175-208. 
Hajli, N., \& Lin, X. (2016). Exploring the security of information sharing on social networking sites: The role of perceived control of information. Journal of Business Ethics, 133(1), 111-123.

Hair, J. F., Hult, G. T. M., Ringle, C. M., \&Sarstedt, M. (2014). A primer on partial least squares structural equation modeling (PLS-SEM). Thousand Oaks, CA: Sage.

Halbouni, S. S. (2015). The Role of Auditors in Preventing, Detecting, and Reporting Fraud: The Case of the United Arab Emirates (UAE). International Journal of Auditing, 19(2), 117-130.

Hampton, C. (2015). Estimating and Reporting Structural Equation Models with Behavioral Accounting Data. Behavioral Research in Accounting 27(2): 1-34.

Hannah, S. T., \&Avolio, B. J. (2010). Moral potency: Building the capacity for characterbased leadership. Consulting Psychology Journal, 62: 291-310.

Hannah, S. T., Avolio, B. J., \& May, D. R. (2011). Moral Maturation and moral conation: A capacity approach to explaining moral thought and action. Academy of Management Review, 36: 663-685.

Hannah, S. T. ,Schaubroeck, J. M., Peng, A. C., Lord , R. G., Trevino , L. K., Kozlowski,S. W. J., Avolio, B. J., Dimotakis, N. \& Doty .J. , ( 2013). Joint Influences of Individual and Work Unit Abusive Supervision on Ethical Intentions and Behaviors: A Moderated Mediation Model. Journal of Applied Psychology, 98 (4), 579-592.

Hannah, Sean T., Sweeney, Patrick J., \& Lester, Paul B. (2010). The courageous mind-set: A dynamic personality system approach to courage. In Pury, Cynthia L. S. (Ed); Lopez, Shane J. (Ed), The psychology of courage: Modern research on an ancient virtue., (pp. 125-148). Washington, DC, US: American Psychological Association, xvi, 247 pp.

Harbour, M., \&Kisfalvi, V. (2014). In the eye of the beholder: An exploration of managerial courage. Journal of Business Ethics, 119(4), 493-515.

Hulland, J. (1999). Use of partial least squares (PLS) in strategic management research: A review of four recent studies. Strategic Management Journal, 20, 195-204.

International Auditing and Assurance Standards Board (IAASB). ISA 610 (Revised March 2013), Using the Work of Internal Auditors. International Federation of Accountants (IFAC), New York. Available at http://www.ifac.org/sites/default/files/publications/files/ISA-610-(Revised-2013).pdf.

Institute of Internal Auditors (IIA). 2009. Organizational Independence. Available athttp://www.theiia.org/guidance/standards-and-guidance/independence/index.cfm?print

Institute of Internal Auditors (IIA). (2002). The IIA's Recommendations to the Conference Committee on H.R. 3703. Altamonte Springs, FL: IIA, 2002.

James, K. (2003). The effects of internal audit structure on perceived financial statement fraud prevention. Accounting Horizons, 17(4): 315-327. 
Jayalakshmy, R., Seetharaman, A. \&Khong, T. W. (2005). The changing role of the auditors. Managerial Auditing Journal, 20(3): 249-271.

Khelil, I., Hussainey, K., and Noubbigh, H. (2016). Audit committee - internal audit interaction and moral courage. Managerial Auditing Journal, 31(4/5), 403-433.

Khelil, I., Hussainey, K. \&Noubbigh, H. (2017). Chief Audit Executives' Perceptions of Drivers of Moral Courage: Tunisian Evidence. International Journal of Accounting, Auditing and Performance Evaluation, forthcoming.

Keenan, J. P. (2000). Blowing the whistle on less serious forms of fraud: A study of executives and managers. Employee Responsibilities and Rights Journal, 12(4), 199-217.

Keil, M., Tiwana, A., Sainsbury, R., and Sneha, S. (2010). Toward a Theory of Whistleblowing Intentions: A Benefit-to-Cost Differential Perspective. Decision Sciences, 41(4), 787-812.

Lee, T. Y., Cheung, C. K., andKwong, W. M. (2012). Resilience as a positive youth development construct: a conceptual review. The Scientific World Journal, 2012.

Lopez, S., O’Byrne, K.K. and Petersen, S. (2003), "Profiling courage", in Lopez, S. and Snyder, C.R. (Eds), Positive Psychology Assessment: A Handbook of Models and Measures, APA, WA, pp. 185-197.

Letzring, T. D., Block, J., andFunder, D. C. (2005). Ego-control and ego-resiliency: Generalization of self-report scales based on personality descriptions from acquaintances, clinicians, and the self. Journal of research in personality, 39(4), 395-422.

Levinson, H. (1965). Reciprocation: The relationship between man and organization. Administrative Science Quarterly, 9, 370-390.

Lisi, I. E. (2016). Determinants and Performance Effects of Social Performance Measurement Systems. Journal of Business Ethics, 1-27.

Liyanarachchi, G. A., \& Adler, R. (2011). Accountants' whistleblowing intentions: The impact of retaliation, age, and gender. Australian Accounting Review, 57(2), 167-182.

Luthans, F., Avolio, B.J., Avey, J.B., 2007a. Psychological Capital (PsyCap) Questionnaire (PCQ). Mind Garden Inc.

Luthans, F., Avolio, B. J., Avey, J. B., \& Norman, S. M. (2007a). Positive psychological capital: Measurement and relationship with performance and satisfaction. Personnel Psychology, 60(3), 541-572.

Luthans, F., Youssef, C.M., Avolio, B.J. (2007c). Psychological Capital. Developing the Human Competitive Edge. Oxford University Press, New York.

Luthans, F., Norman, S. M., Avolio, B. J., \&Avey, J. B. (2008b). The mediating role of psychological capital in the supportive organizational climate-employee performance relationship. Journal of Organizational Behavior, 29(2), 219-238. 
May, D. R., Luth, M. T., \&Schwoerer, C. E. (2014). The influence of business ethics education on moral efficacy, moral meaningfulness, and moral courage: A quasiexperimental study. Journal of Business Ethics, 124(1), 67-80.

Mat Zain, M., Subramaniam, N. and Stewart, J. (2006). Internal auditors' assessment of their contribution to financial statement audits: the relationship with audit committee and internal audit function characteristics. International Journal of Auditing, 10(1), 1-18.

Matt, B. F., \&Shahinpoor, N. (2011). Speaking truth to power: The courageous organizational dissenter. In D. R. Comer \& G. Vega (Eds.), Moral courage in organizations: Doing the right thing at work (pp. 157-170). Armonk: M.E. Sharpe.

Mayer, D. M., Nurmohamed, S., Treviño, L. K., Shapiro, D. L., \& Schminke, M. (2013). Encouraging employees to report unethical conduct internally: It takes a village. Organizational Behavior and Human Decision Processes, 121(1), 89-103.

McAdams, D. P., \& Pals, J. L. (2006). A new Big Five: Fundamental principles for an integrative science of personality. American Psychology, 61(3), 204-217.

Miceli, M. P., Near, J. P., \& Morehead Dwoekin, T. (2008). Whistleblowing in organizations. New York: Routledge.

Miceli, M. P., \& Near, J. P. (1988). Individual and situational correlates of whistleblowing. Personnel Psychology, 41(2), 267-281.

Moberg, D. J. (1999). The Big Five and organizational virtue. Business Ethics Quarterly, $9(2), 245-272$.

Morales-Sánchez, R., \& Cabello-Medina, C. (2013). The Role of Four Universal Moral Competencies in Ethical Decision-Making. Journal of business ethics, 116 (4), 717-734.

Murphy, K. R., \&Davidshofer, C. O. (1988). Psychological testing. Principles, and Applications, Englewood Cliffs.

Mutchler, J.F. (2003). Independence and objectivity: A framework for research opportunities in internal auditing, in Research Opportunities in Internal Auditing edited by Bailey, A.D., A.A. Gramling and S. Ramamoorti, Chapter 7, The Institute of Internal Auditors Research Foundation: Altamonte Springs, FL, 231-268.

Osswald, S., Frey, D. and Streicher, B. (2012). Moral courage. In Kals, E. and Maes, J. (Eds), Justice and Conflicts, Springer, Berlin, Heidelberg, pp. 391-405.

Parker, S. K. (1998). Enhancing role breadth self-efficacy: the roles of job enrichment and other organizational interventions. Journal of Applied Psychology, 83(6), 835.

Peterson, S. J., \& Luthans, F. (2003). The positive impact and development of hopeful leaders. Leadership \& Organization Development Journal, 24(1), 26-31. 
Pury, C., Kowalski, R., \& Spearman, J. (2007). Distinctions between general and personal courage. The Journal of Positive Psychology, 2, 99-114.

Rhoades, L., \&Eisenberger, R. (2002). Perceived organizational support: a review of the literature. Journal of applied psychology, 87(4), 698-714.

Rhoades, L., Eisenberger, R., \&Armeli, S. (2001). Affective commitment to the organization: the contribution of perceived organizational support. Journal of applied psychology, 86(5), 825.

Rice, F. P. (1998). Human development: A life-span approach. Upper Saddle River, NJ: Prentice Hall.

Sarens, G., De Beelde, I., \&Everaert, P. (2009). Internal audit: A comfort provider to the audit committee. The British Accounting Review, 41(2), 90-106.

Scarbrough, P., Rama, D. and Raghunandan, K. (1998). Audit committee composition and interaction with internal auditing: Canadian evidence. Accounting Horizons, 12(1), 51-62.

Shanock, L. R., \& Eisenberger, R. (2006). When supervisors feel supported: relationships with subordinates' perceived supervisor support, perceived organizational support, and performance. Journal of Applied psychology, 91(3), 689.

Schaubroeck, J., Hannah, S. T., Avolio, B. J., Kozlowski, S. W. J., Lord, R. L., Treviño, L. K., Peng, A. C., \& Dimotakas, N. 2012. Embedding ethical leadership within and across organization levels. Academy of Management Journal, 50: 1053-1078.

Sekerka, L. E. (2011). Preserving integrity in the face of corruption: Exercising moral courage in the path to right action. Journal of Moral Philosophy, 1(3), 1-14.

Sekerka, L. E., \&Bagozzi, R. P. (2007). Moral Courage in the Workplace: Moving to and from the Desire and Decision to Act. Business Ethics: A European Review, 16, 132149.

Sekerka, L.E., Bagozzi, R.P. and Charnigo, R. (2009). Facing ethical challenges in the workplace: conceptualizing and measuring professional moral courage. Journal of Business Ethics, 89 (4), 565-579.

Skitka. J. L. (2012). Moral Convictions and Moral Courage: Common Denominators of Good and Evil. J. Mikulincer, Mario (Ed); Shaver, Phillip R. (Ed), (2012). The social psychology of morality: Exploring the causes of good and evil. Herzliya series on personality and social psychology. (pp. 349-365). Washington, DC, US: American Psychological Association, xvi, 440 pp.

Snyder, C. R., Harris, C, Anderson, J. R., Holleran, S. A., Irving, L. M., Sigmon, S. T, Yoshinobu, L., Gibb, J., Langelle, C, \&Hamey, P. (1991). The will and the ways: Development and validation of an individual-differences measure of hope. Journal of Personality and Social Psychology, 60, 570-5. 
Snyder, C. R., Sympson, S. C., Ybasco, F. C., Borders, T. F., Babyak, M. A. and Higgins, R. L. (1996). Development and validation of the state hope scale. Journal of Personality and Social Psychology, 70, 321-35.

Stewart, J. and Subramaniam, N. (2010). Internal audit independence and objectivity: emerging research opportunities. Managerial Auditing Journal, 25(4), 328-360.

The Organization for Economic Cooperation and Development (OECD 2014) http://www.oecd.org/fr/pays/tunisie/

Turley, S. and Zaman, M. (2007). Audit committee effectiveness: informal processes and behavioural effects. Accounting, Auditing \& Accountability Journal, 20(5) pp. 765-788.

Vroom, V.: 1964, Work and Motivation (John Wiley \& Sons, Inc., New York).

Xu, Y., \&Ziegenfuss, D. E. (2008). Reward systems, moral reasoning, and internal auditors' reporting wrongdoing. Journal of Business and Psychology, 22(4), 323-331.

Youssef, C.M., Luthans, F. (2012). Psychological capital. Meaning, findings and future directions. In: Cameron, K.S., Spreitzer, G.M. (Eds.), the Oxford Handbook of Positive Organizational Scholarship. Oxford University Press, New York, pp. 17-27.

Zaman, M. and Sarens, G. (2013). Informal interactions between audit committees and internal audit functions: exploratory evidence and directions for future research. Managerial Auditing Journal, 28(6), 495-515. 
Table 1. Demographic variables and sample composition

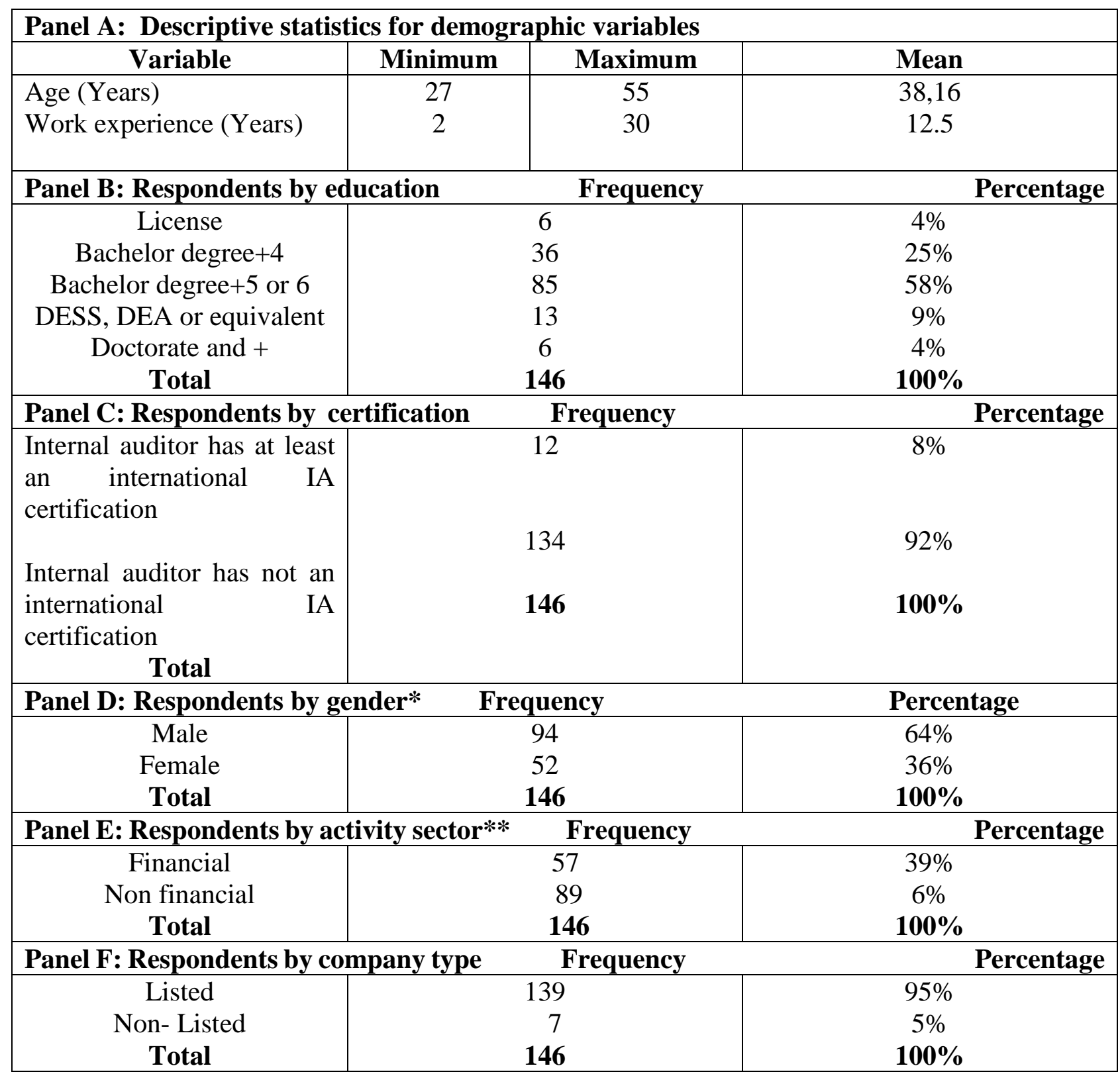

*Gendercoded $0=$ male, $1=$ female

** Activity sectorcoded $0=$ non financial, $1=$ financial 
Table 2. Descriptive statistics for scale variables

\begin{tabular}{|c|c|c|c|c|}
\hline & Mean & SD & $\begin{array}{c}\text { Theoretical } \\
\text { range }\end{array}$ & Actual range \\
\hline Moral courage & 3.955 & 0.965 & $1-5$ & $1.75-5$ \\
\hline $\begin{array}{l}\text { IAF } \\
\text { independence }\end{array}$ & 0.137 & 0.098 & NA & NA \\
\hline Pathway & 4.187 & 0.572 & $1-5$ & $1.667-5$ \\
\hline Agency & 3.887 & 0.728 & $1-5$ & $1.333-5$ \\
\hline $\begin{array}{l}\text { Resilience } \\
\text { Perceived }\end{array}$ & 3.648 & 0.923 & $1-5$ & $1.571-5$ \\
\hline $\begin{array}{l}\text { Perceived } \\
\text { Supervisor } \\
\text { Support }\end{array}$ & 3.811 & 0.881 & $1-5$ & $2.25-5$ \\
\hline Self-efficacy & 4.009 & 1.008 & $1-5$ & $1.6-5$ \\
\hline
\end{tabular}


Table 3. Item loadings, composite reliability and AVE statistics for all variables $(n=127)$

\begin{tabular}{|c|c|c|}
\hline & $\begin{array}{r}\text { Final } \\
\text { model }\end{array}$ & $\begin{array}{l}\text { Initial } \\
\text { model }\end{array}$ \\
\hline \multicolumn{3}{|l|}{ Moral courage } \\
\hline COURAGE1: I will confront my peers if they commit an unethical act & 0.911 & 0.911 \\
\hline $\begin{array}{l}\text { COURAGE 2: I will confront my manager if she/she commits an unethical } \\
\text { act. }\end{array}$ & 0.956 & 0.956 \\
\hline $\begin{array}{l}\text { COURAGE 3: I will always state my views about ethical issues to my } \\
\text { supervisors. }\end{array}$ & 0.948 & 0.948 \\
\hline $\begin{array}{l}\text { COURAGE 4: I will go against the group's decision whenever it violates } \\
\text { my ethical standards }\end{array}$ & 0.953 & 0.953 \\
\hline Composite reliability & 0.969 & 0.969 \\
\hline Cronbach's alpha & 0.958 & 0.958 \\
\hline$A V E$ & 0.888 & 0.888 \\
\hline \multicolumn{3}{|l|}{ State Hope } \\
\hline \multicolumn{3}{|l|}{ Pathway } \\
\hline $\begin{array}{l}\text { HOP1: If I should find myself in a jam, I could think of ways to get out of } \\
\text { it. }\end{array}$ & & -0.493 \\
\hline $\begin{array}{l}\text { HOP3: There are lots of ways around any problem that I am facing now. } \\
\text { HOP5: I can think of many wavs to reach my current goals. }\end{array}$ & 1.000 & $\begin{array}{r}0.874 \\
-0.020\end{array}$ \\
\hline Composite reliability & $N A^{a}$ & 0.061 \\
\hline Cronbach's alpha & $N A$ & -0.349 \\
\hline$A V E$ & $N A$ & 0.336 \\
\hline \multicolumn{3}{|l|}{ Agency } \\
\hline HOP2: At the present time, I am energetically pursuing my goals. & & 0.413 \\
\hline HOP4: Right now, I see myself as being pretty successful. & 1.000 & 0.671 \\
\hline HOP6: At this time, I am meeting the goals that I have set for myself. & & 0.719 \\
\hline Composite reliability & $N A$ & 0.636 \\
\hline Cronbach's alpha & $N A$ & 0.259 \\
\hline $\boldsymbol{A V E}$ & $N A$ & 0.380 \\
\hline \multicolumn{3}{|l|}{ Resilience } \\
\hline RES1: I am generous with my friends. & & 0.552 \\
\hline RES2: I quickly get over and recover from being startled. & & 0.699 \\
\hline RES3: I enjoy dealing with new and unusual situations. & 0.847 & 0.841 \\
\hline RES4: I usually succeed in making a favorable impression on people. & 0.834 & 0.785 \\
\hline RES5: I enjoy trying new foods I have never tasted before. & & 0.598 \\
\hline RES6: I am regarded as a very energetic person. & & 0.676 \\
\hline RES7: I like to take different paths to familiar places. & 0.749 & 0.757 \\
\hline RES8: I am more curious than most people. & 0.819 & 0.774 \\
\hline RES9: Most of the people I meet are likable. & & 0.576 \\
\hline RES10: I usually think carefully about something before acting. & & 0.566 \\
\hline RES11: I like to do new and difficult things. & 0.905 & 0.913 \\
\hline RES12: My daily life is full of things that keep me interested. & 0.817 & 0.772 \\
\hline
\end{tabular}


RES13: I would be willing to describe myself as a pretty 'strong' personality.

RES14: I get over my anger at someone reasonably quickly.

$0.825 \quad 0.833$

Composite reliability

$0.945 \quad 0.940$

Cronbach's alpha

0.9320 .932

AVE

$0.682 \quad 0.536$

\section{Perceived Supervisor Support}

PSS1: My Audit Committee/Board of Directors strongly considers my goals and values

$0.939 \quad 0.939$

PSS2: Help is available from my Audit Committee/Board of Directors when I have a problem.

$0.891 \quad 0.891$

PSS3: My Audit Committee/Board of Directors really cares about my wellbeing.

$0.945 \quad 0.945$

PSS4: My Audit Committee/Board of Directors would forgive an honest mistake on my part.

$0.842 \quad 0.842$

PSS5: If given the opportunity, my Audit Committee/Board of Directors would take advantage of me. (R)

$0.799 \quad 0.799$

PSS6: My Audit Committee/Board of Directors is willing to help me if I need a special favor.

$0.862 \quad 0.862$

PSS7: My Audit Committee/Board of Directors shows very little concern for me. (R)

$0.871 \quad 0.871$

PSS8: My Audit Committee/Board of Directors cares about my opinions.

$0.896 \quad 0.896$

Composite reliability

0.9650 .965

Cronbach's alpha

0.9590 .959

$A V E$

$0.777 \quad 0.777$

Self confidence

S-EFF1: Analyzing a long-term problem to find a solution

$0.736 \quad 0.736$

S-EFF2: Representing your work area in meetings with senior management

$0.920 \quad 0.920$

S-EFF3: Designing new procedures for your work area

$0.829 \quad 0.829$

S-EFF4: Making suggestions to management about ways to improve the working of your section

$0.953 \quad 0.953$

S-EFF5: Contributing to discussions about the company's strategy

$0.910 \quad 0.910$

S-EFF6: Writing a proposal to spend money in your work area $\quad 0.950 \quad 0.950$

S-EFF7: Helping to set targets/goals in your work area

$0.811 \quad 0.811$

S-EFF8: Contacting people outside the company (e.g., suppliers, customers) to discuss problems

$0.924 \quad 0.924$

S-EFF9: Presenting information to a group of colleagues

$0.801 \quad 0.801$

S-EFF10: Visiting people from other departments to suggest doing things

$0.861 \quad 0.861$ differently

Composite reliability

0.9690 .969

Cronbach's alpha

$0.964 \quad 0.964$

$\boldsymbol{A V E}$

$0.761 \quad 0.761$ 
Table 4. Inter-construct correlations and square root of AVE statistics ${ }^{c}(n=127)$

\begin{tabular}{|c|c|c|c|c|c|c|c|}
\hline & $\begin{array}{c}\text { Agenc } \\
y\end{array}$ & $\begin{array}{l}\text { Independe } \\
\text { nce }\end{array}$ & $\begin{array}{c}\text { Moral } \\
\text { Courage }\end{array}$ & $\begin{array}{c}\text { Pathwa } \\
\mathrm{y}\end{array}$ & $\begin{array}{c}\text { Resilien } \\
\text { ce }\end{array}$ & $\begin{array}{c}\text { Self } \\
\text { efficac } \\
\mathrm{y} \\
\end{array}$ & $\begin{array}{c}\text { Support } \\
\text { supervis } \\
\text { or }\end{array}$ \\
\hline Agency & 1.000 & & & & & & \\
\hline Independence & -0.017 & 1.000 & & & & & \\
\hline Moral Courage & 0.242 & 0.002 & 1.000 & & & & \\
\hline Pathway & 0.079 & 0.031 & 0.359 & 1.000 & & & \\
\hline Resilience & 0.308 & -0.060 & 0.724 & 0.326 & 0.820 & & \\
\hline Self-efficacy & 0.351 & -0.089 & 0.782 & 0.222 & 0.734 & 0.833 & \\
\hline $\begin{array}{l}\text { Perceived Support } \\
\text { supervisor }\end{array}$ & 0.375 & -0.104 & 0.811 & 0.325 & 0.763 & 0.920 & 0.863 \\
\hline
\end{tabular}

${ }^{c}$ Diagonal elements are the square roots of AVEs. Off-diagonal elements are the correlations between constructs 
Table 5. Inter-construct correlations and square root of AVE statistics ${ }^{\mathrm{d}}(\mathrm{n}=144)$ (first model)

\begin{tabular}{|c|c|c|c|c|c|c|c|}
\hline & CR & $\begin{array}{c}\text { Agenc } \\
y\end{array}$ & $\begin{array}{c}\text { Independenc } \\
\mathrm{e}\end{array}$ & $\begin{array}{c}\text { Moral } \\
\text { Courage }\end{array}$ & Pathway & $\begin{array}{c}\text { Resilienc } \\
\mathrm{e}\end{array}$ & $\begin{array}{c}\text { Support } \\
\text { superviso } \\
\mathrm{r}\end{array}$ \\
\hline Agency & 1.000 & 1.000 & & & & & \\
\hline Independence & 1.000 & -0.070 & 1.000 & & & & \\
\hline Moral Courage & 1.000 & 0.257 & -0.014 & 1.000 & & & \\
\hline Pathway & 1.000 & 0.211 & -0.028 & 0.378 & 1.000 & & \\
\hline Resilience & 0.935 & 0.287 & -0.089 & 0.727 & 0.393 & 0.820 & \\
\hline $\begin{array}{l}\text { Perceived } \\
\text { supervisor } \\
\text { Support }\end{array}$ & 0.940 & 0.349 & -0.101 & 0.826 & 0.375 & 0.775 & 0.871 \\
\hline
\end{tabular}

CR: composite reliability

${ }^{\mathrm{d} D i a g o n a l}$ elements are the square roots of AVEs. Off-diagonal elements are the correlations between constructs

Table 6. Inter-construct correlations and square root of AVE statistics ${ }^{\mathrm{e}}(\mathrm{n}=143)$ (second model)

\begin{tabular}{|c|c|c|c|c|c|c|c|}
\hline & $\mathrm{CR}$ & $\begin{array}{c}\text { Agenc } \\
y\end{array}$ & $\begin{array}{c}\text { Independenc } \\
\mathrm{e}\end{array}$ & $\begin{array}{c}\text { Moral } \\
\text { Courage }\end{array}$ & Pathway & $\begin{array}{c}\text { Resilien } \\
\text { ce }\end{array}$ & $\begin{array}{c}\text { Self- } \\
\text { efficacy }\end{array}$ \\
\hline Agency & 1.000 & 1.000 & & & & & \\
\hline Independence & 1.000 & -0.051 & 1.000 & & & & \\
\hline $\begin{array}{l}\text { Moral } \\
\text { Courage }\end{array}$ & 1.000 & 0.220 & -0.001 & 1.000 & & & \\
\hline Pathway & 1.000 & 0.130 & -0.004 & 0.345 & 1.000 & & \\
\hline Resilience & 0.934 & 0.264 & -0.081 & 0.722 & 0.375 & 0.819 & \\
\hline Self-efficacy & 0.919 & 0.304 & -0.084 & 0.804 & 0.266 & 0.747 & 0.833 \\
\hline
\end{tabular}

CR: composite reliability

${ }^{\mathrm{e}}$ Diagonal elements are the square roots of AVEs. Off-diagonal elements are the correlations between constructs 
Table 7. PLS structural model: path coefficients, $t$-statistics and $R^{2}(n=144)$ (first model)

\begin{tabular}{lllllll}
\hline & $\begin{array}{c}\text { Standardizedp } \\
\text { ath } \\
\text { Coefficient }\end{array}$ & $\begin{array}{c}\text { STDE } \\
\text { V }\end{array}$ & $\begin{array}{c}\text { T } \\
\text { value }\end{array}$ & $\begin{array}{c}\text { P } \\
\text { Values }\end{array}$ & Decision & $\begin{array}{l}\text { Hypot } \\
\text { hesis }\end{array}$ \\
\hline Agency -> MC & -0.042 & 0.046 & 0.915 & 0.360 & $\begin{array}{l}\text { Not } \\
\text { Supported }\end{array}$ & H2.a \\
Independence -> MC & 0.070 & 0.033 & 2.146 & $0.032 *$ & Supported & H5 \\
Pathway -> MC & 0.058 & 0.061 & 0.941 & 0.347 & $\begin{array}{l}\text { Not } \\
\text { Supported }\end{array}$ & H2.b \\
$\begin{array}{l}\text { Perceived support supervisor - - } \\
\text { MC }\end{array}$ & 0.667 & 0.087 & 7.702 & $0.000^{*}$ & Supported & H3 \\
$\begin{array}{l}\text { Resilience -> MC } \\
\mathbf{R}^{2}\end{array}$ & 0.206 & 0.097 & 2.128 & $0.034 *$ & Supported & H4 \\
\hline
\end{tabular}

MC : Moral courage

*Significance at the level of 0.05

Table 8. PLS structural model: path coefficients, t-statistics and $\mathrm{R}^{2}(\mathrm{n}=143)$ (second model)

\begin{tabular}{|c|c|c|c|c|c|c|}
\hline & $\begin{array}{c}\text { Standardizedpath } \\
\text { Coefficient }\end{array}$ & STDEV & $\begin{array}{c}\mathrm{T} \\
\text { value }\end{array}$ & $\begin{array}{c}\mathrm{P} \\
\text { Values }\end{array}$ & Decisions & $\begin{array}{l}\text { Hypothe } \\
\text { sis }\end{array}$ \\
\hline Agency -> MC & -0.040 & 0.048 & 0.847 & 0.398 & $\begin{array}{l}\text { Not } \\
\text { supported }\end{array}$ & $\mathrm{H} 2 . \mathrm{a}$ \\
\hline $\begin{array}{l}\text { Independence } \\
\mathrm{MC}\end{array}$ & 0.068 & 0.033 & 2.032 & $0.043 *$ & Supported & H5 \\
\hline Pathway -> MC & 0.096 & 0.053 & 1.794 & 0.073 & $\begin{array}{l}\text { Not } \\
\text { supported }\end{array}$ & $\mathrm{H} 2 . \mathrm{b}$ \\
\hline Resilience -> MC & 0.243 & 0.095 & 2.564 & $0.011^{*}$ & Supported & H3 \\
\hline Self efficacy $->$ MC & 0.615 & 0.082 & 7.517 & $0.000 *$ & Supported & $\mathrm{H} 1$ \\
\hline $\mathbf{R}^{2}$ & \multicolumn{6}{|c|}{0.694} \\
\hline
\end{tabular}

MC : Moral courage

*Significance at the level of 0.05 
Table 9. PLS structural model after the integration of gender

\begin{tabular}{|c|c|c|c|c|c|c|c|c|}
\hline & \multicolumn{4}{|c|}{ First model } & \multicolumn{4}{|c|}{ Second model } \\
\hline & $\begin{array}{c}\text { Standardi } \\
\text { zedpath } \\
\text { Coefficie } \\
\text { nt }\end{array}$ & $\begin{array}{c}\text { Stand } \\
\text { ard } \\
\text { Devi } \\
\text { ation }\end{array}$ & $\begin{array}{c}\mathrm{T} \\
\text { Stati } \\
\text { stics }\end{array}$ & $\begin{array}{c}\mathrm{P} \\
\text { Val } \\
\text { ues } \\
\end{array}$ & $\begin{array}{c}\text { Standardi } \\
\text { zedpath } \\
\text { Coefficie } \\
\text { nt }\end{array}$ & $\begin{array}{l}\text { Standard } \\
\text { Deviation }\end{array}$ & $\begin{array}{c}\mathrm{T} \\
\text { Statist } \\
\text { ics }\end{array}$ & $\begin{array}{c}\text { P } \\
\text { Valu } \\
\text { es }\end{array}$ \\
\hline Gender -> MC & 0.115 & 0.045 & $\begin{array}{r}2.55 \\
5\end{array}$ & $\begin{array}{r}0.0 \\
11^{*}\end{array}$ & 0.127 & 0.044 & 2.917 & $\begin{array}{r}0.00 \\
4 *\end{array}$ \\
\hline Agency -> MC & -0.045 & 0.048 & $\begin{array}{r}0.93 \\
2\end{array}$ & $\begin{array}{r}0.3 \\
52\end{array}$ & -0.047 & 0.048 & 0.986 & $\begin{array}{r}0.32 \\
5\end{array}$ \\
\hline Independence -> MC & 0.065 & 0.033 & $\begin{array}{r}1.98 \\
0\end{array}$ & $\begin{array}{r}0.0 \\
48 *\end{array}$ & 0.063 & 0.029 & 2.130 & $\begin{array}{r}0.03 \\
4 *\end{array}$ \\
\hline Pathway -> MC & 0.060 & 0.064 & $\begin{array}{r}0.94 \\
0\end{array}$ & $\begin{array}{r}0.3 \\
48\end{array}$ & 0.095 & 0.054 & 1.756 & $\begin{array}{r}0.08 \\
0\end{array}$ \\
\hline Resilience -> MC & 0.179 & 0.088 & $\begin{array}{r}2.02 \\
9\end{array}$ & $\begin{array}{r}0.0 \\
43^{*}\end{array}$ & 0.213 & 0.089 & 2.408 & $\begin{array}{r}0.01 \\
6^{*}\end{array}$ \\
\hline $\begin{array}{l}\text { Perceived support } \\
\text { supervisor } \rightarrow \mathrm{MC}\end{array}$ & 0.686 & 0.079 & $\begin{array}{r}8.72 \\
9\end{array}$ & $\begin{array}{r}\mathbf{0 . 0} \\
\mathbf{0 0} *\end{array}$ & & & & \\
\hline Self efficacy -> MC & & & & & 0.638 & 0.076 & 8.410 & $\begin{array}{r}\mathbf{0 . 0 0} \\
0 *\end{array}$ \\
\hline
\end{tabular}

MC : Moral courage

*Significance at the level of 0.05 


\section{Appendix Questionnaire}

Questionnaire $\mathrm{n}^{\circ} \ldots$.

Date......

As part of the development of our thesis on the internal auditor, I offer you a questionnaire that will be used to collect data to address our study objectives. It should be noted that the information collected will be treated confidentially.

I would be grateful for your collaboration and your close involvement in this project.

Company Name /Sector

\section{Part 1: General Information about Internal Auditor}

\begin{tabular}{|c|c|c|c|c|}
\hline 1.Gender & Male & \multicolumn{3}{|c|}{ Female } \\
\hline \multirow{9}{*}{ 2.Training level } & \multicolumn{4}{|c|}{ Level } \\
\hline & \multicolumn{3}{|c|}{ Baccalaureate or equivalent } & \\
\hline & \multicolumn{3}{|c|}{$\begin{array}{l}\text { Baccalaureate degree }+2 \\
\text { or equivalent }\end{array}$} & \\
\hline & \multicolumn{3}{|c|}{ Baccalaureate degree $+3=$ license } & \\
\hline & \multicolumn{3}{|c|}{ Baccalaureatedegree +4} & \\
\hline & \multicolumn{3}{|c|}{ Baccalaureate degree +5 or +6} & \\
\hline & \multicolumn{3}{|c|}{ DESS, DEA or equivalent } & \\
\hline & \multicolumn{3}{|c|}{ Doctorate and + } & \\
\hline & \multicolumn{3}{|l|}{ Other } & \\
\hline 3. The number of years of experience & \multicolumn{4}{|c|}{ 4. Age } \\
\hline 5. Certifications & CIA & DPAI & CISA & Other \\
\hline
\end{tabular}

Part 2: For questions 1 thru 5, think about your typical actions and rate your level of agreement with how each statement below applies to your behavior. Use the following scale to indicate your level of agreement or disagreement with each statement. 


\begin{tabular}{|c|c|c|c|c|}
\hline $\begin{array}{c}\text { Strongly } \\
\text { Disagree }\end{array}$ & Disagree & Neutral & Agree & Strongly Agree \\
$\mathbf{1}$ & 2 & 3 & 4 & 5 \\
\hline
\end{tabular}

\begin{tabular}{|c|c|}
\hline Statement & $\begin{array}{r}\text { Level of } \\
\text { agreement } \\
\text { (circle one } \\
\text { number) }\end{array}$ \\
\hline 1a. I will confront my peers if they commit an unethical act & 12345 \\
\hline 1b. I will confront my manager if she/she commits an unethical act. & 12345 \\
\hline 1c. I will always state my views about ethical issues to my supervisors. & 123345 \\
\hline 1d. I will go against the group's decision whenever it violates my ethical standards. & 12345 \\
\hline 2a. Internal audit reports to the Audit Committee & 123345 \\
\hline 2b. Internal audit reports to the Chief Financial Officer (CFO) & 12345 \\
\hline 2c. Internal audit reports to the Chief Executive Officer (CEO) & 12345 \\
\hline 2d. The Audit Committee has authorization to terminate the Chief Audit Executive & 123345 \\
\hline 2e. The CFO has authorization to terminate the Chief Audit Executive & 123345 \\
\hline 2f. The CEO has authorization to terminate the Chief Audit Executive & 12345 \\
\hline 2g. The Audit Committee determines Internal Audit's annual budget & 123345 \\
\hline 2h. The CFO determines Internal Audit's annual budget & 123345 \\
\hline 2i. The CEO determines Internal Audit's annual budget & 123345 \\
\hline 3a. If I should find myself in a jam, I could think of ways to get out of it. & 123345 \\
\hline 3b. At the present time, I am energetically pursuing my goals. & 12345 \\
\hline 3c. There are lots of ways around any problem that I am facing now. & 123345 \\
\hline 3d. Right now, I see myself as being pretty successful. & 123345 \\
\hline 3e. I can think of many ways to reach my current goals. & 123345 \\
\hline 3f. At this time, I am meeting the goals that I have set for myself. & 12345 \\
\hline 4a. I am generous with my friends. & 123345 \\
\hline 4b. I quickly get over and recover from being startled. & 12345 \\
\hline 4c. I enjoy dealing with new and unusual situations. & 123345 \\
\hline 4d. I usually succeed in making a favorable impression on people. & 123345 \\
\hline 4e. I enjoy trying new foods I have never tasted before. & 123345 \\
\hline 4f. I am regarded as a very energetic person. & 123345 \\
\hline 4g. I like to take different paths to familiar places. & 123345 \\
\hline 4h. I am more curious than most people. & 123345 \\
\hline 4i. Most of the people I meet are likable. & 123345 \\
\hline 4j. I usually think carefully about something before acting. & 123345 \\
\hline 4k. I like to do new and difficult things. & 12345 \\
\hline 41. My daily life is full of things that keep me interested. & 123345 \\
\hline 4m. I would be willing to describe myself as a pretty 'strong' personality. & 123345 \\
\hline 4n. I get over my anger at someone reasonably quickly. & 123345 \\
\hline 5a. My Audit Committee strongly considers my goals and values. & 123345 \\
\hline
\end{tabular}


5b. Help is available from my Audit Committee when I have a problem.

\begin{tabular}{llllll}
1 & 2 & 3 & 4 & 5 \\
\hline
\end{tabular}

5c. My Audit Committee really cares about my well-being. $\begin{array}{lllll}1 & 2 & 3 & 4 & 5\end{array}$

5d. My Audit Committee would forgive an honest mistake on my part. $\begin{array}{llllll}1 & 2 & 3 & 4 & 5\end{array}$

5e. If given the opportunity, my Audit Committee would take advantage of me. (R)

5f. My Audit Committee is willing to help me if I need a special favor.

\begin{tabular}{lllll|l}
1 & 2 & 3 & 4 & 5 \\
\hline & 1 & 2 & 3 & 4 & 5
\end{tabular}

5g. My Audit Committee shows very little concern for me. (R)

$\begin{array}{llllll}1 & 2 & 3 & 4 & 5\end{array}$

5h. My Audit Committee cares about my opinions.

\begin{tabular}{llllll}
1 & 2 & 3 & 4 & 5 \\
\hline
\end{tabular}

$\begin{array}{llllll}1 & 2 & 3 & 4 & 5\end{array}$

\section{How confident do you feel if you are asked to carry out each of the 10 tasks?}

\begin{tabular}{|r|r|r|r|r|}
\hline $\begin{array}{r}\text { Not at all } \\
\text { confident }\end{array}$ & Not confident & $\begin{array}{r}\text { Neutral } \\
3\end{array}$ & Confident & very confident \\
1 & 2 & 4 & 5 \\
\hline
\end{tabular}

\begin{tabular}{|c|c|}
\hline 6a. Analyzing a long-term problem to find a solution & 12345 \\
\hline 6b. Representing your work area in meetings with senior management & 12345 \\
\hline 6c. Designing new procedures for your work area & 12345 \\
\hline $\begin{array}{l}\text { 6d. Making suggestions to management about ways to improve the working of your } \\
\text { section }\end{array}$ & 12345 \\
\hline 6e. Contributing to discussions about the company's strategy & 12345 \\
\hline 6f. Writing a proposal to spend money in your work area & 12345 \\
\hline 6g. Helping to set targets/goals in your work area & 122345 \\
\hline $\begin{array}{l}\text { 6h. Contacting people outside the company (e.g., suppliers, customers) to discuss } \\
\text { problems }\end{array}$ & 12345 \\
\hline 6i. Presenting information to a group of colleagues & 12345 \\
\hline 6j.Visiting people from other departments to suggest doing things differently & 12345 \\
\hline
\end{tabular}


Figure 1. General theoretical model

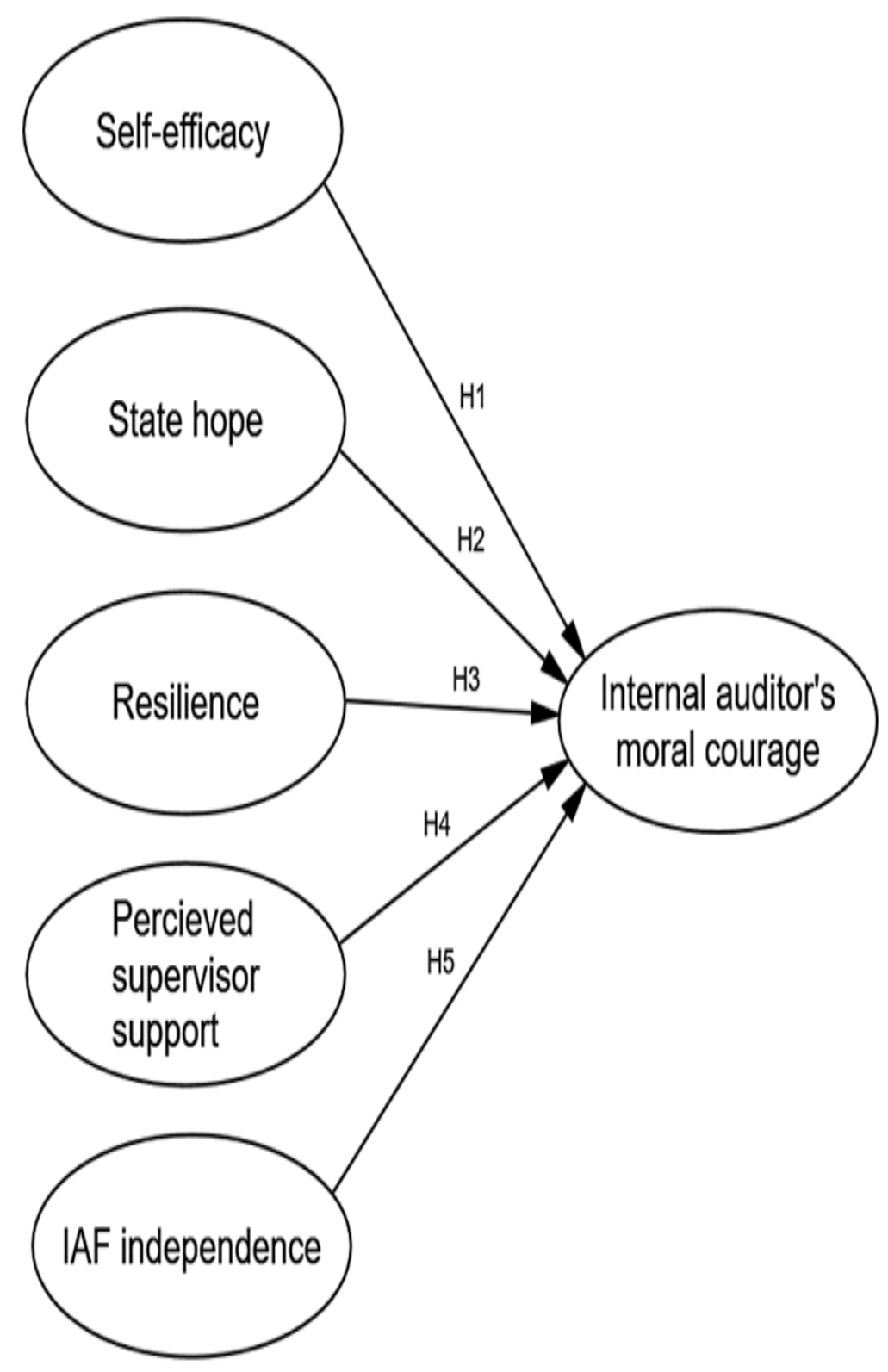


Figure 2. PLS structural model

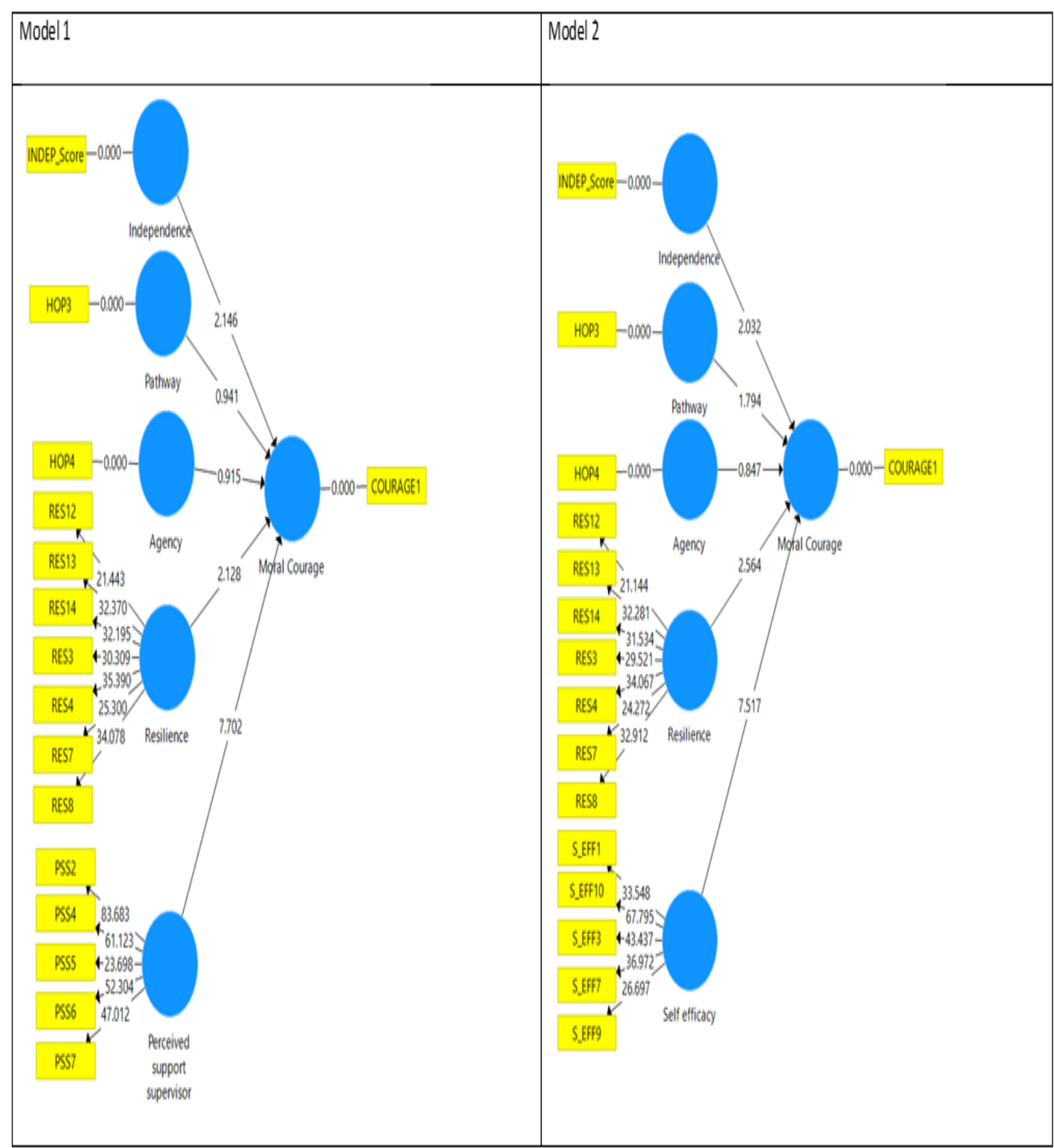

